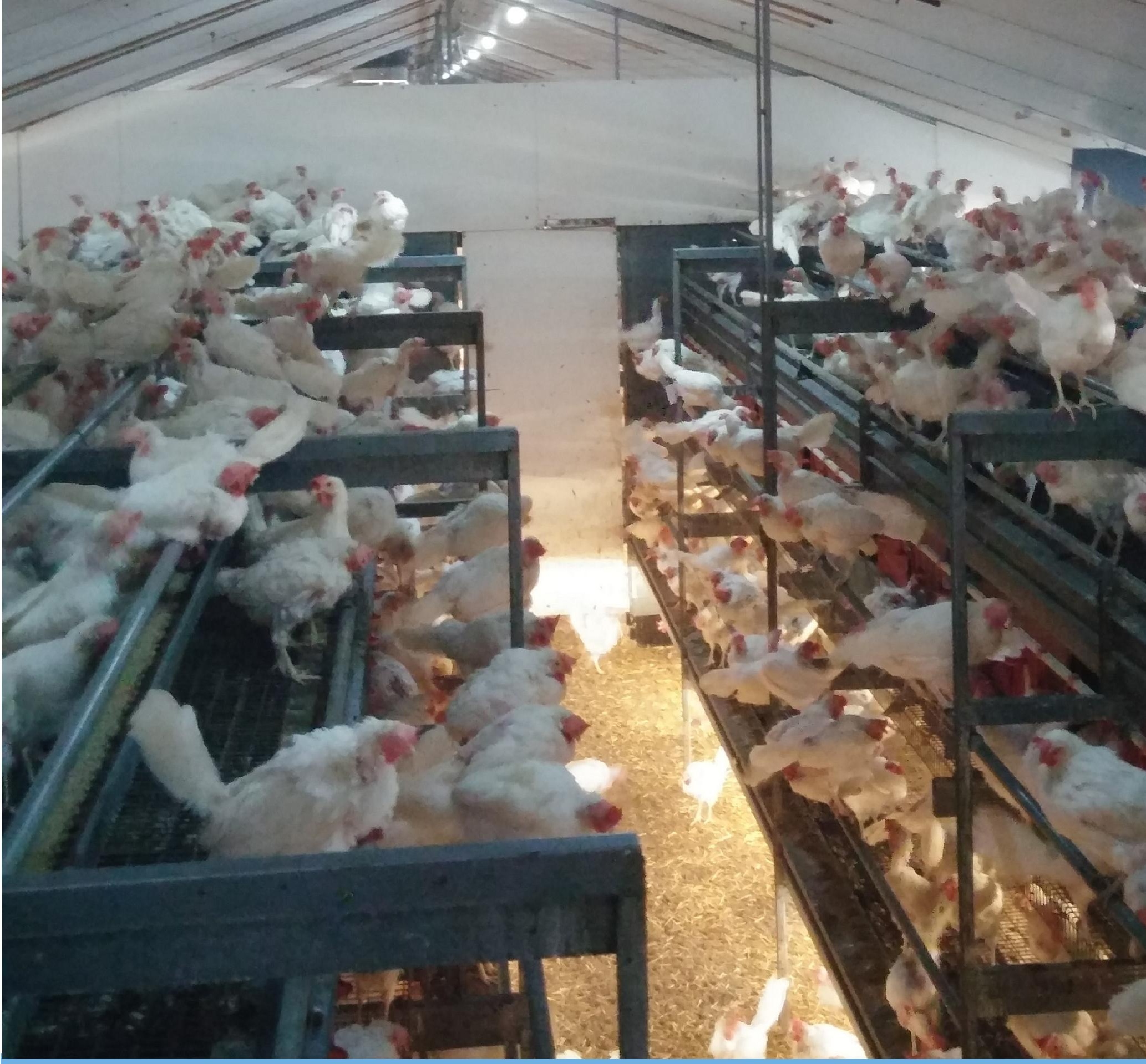

Pilots naar de vermindering van fijnstofemissie uit pluimveestallen

HD-ionisatielampen van Freshlight

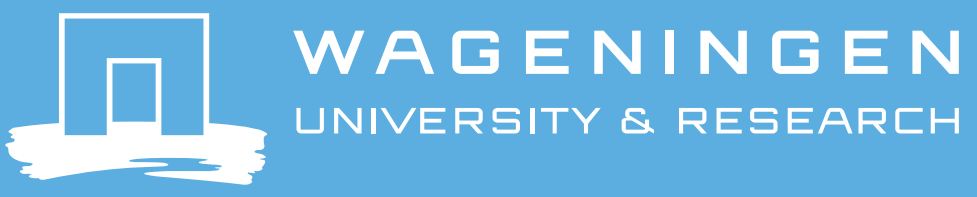





\section{Pilots naar de vermindering van fijnstofemissie uit pluimveestallen: HD-ionisatielampen van Freshlight}

Yvo Goselink, Hilko Ellen, Jos Huis in 't Veld, Albert Winkel

Voorstel foto voorkant: 
Goselink, Y., H. Ellen, J. Huis in 't Veld, A. Winkel, 2020. Pilots naar de vermindering van fijnstofemissie uit pluimveestallen: de HD-ionisatielampen van Freshlight. Wageningen Livestock Research, Rapport 1217.

Om de blootstelling aan fijnstof in veehouderijgebieden te verlagen zijn technieken nodig die de emissie uit pluimveestallen kunnen verminderen. In deze pilot zijn metingen verricht aan de HDionisatielampen van de firma Freshlight, geïnstalleerd in een leghennenstal. In afwijking van de meetprotocollen is er in de zogenaamde "fijnstof pilots" aan één (in plaats van twee) bedrijfslocaties gemeten. Uit de metingen blijkt dat het systeem de emissie van fijnstof $\left(\mathrm{PM}_{10}\right)$ met gemiddeld $41 \%$ vermindert.

To mitigate the concentrations of fine particulate matter in livestock farming areas, techniques are needed which reduce emissions from poultry barns. In this pilot study, measurements were carried out on the ionization lights of the company Freshlight, installed inside a layer barn. In deviation from the measurement protocols, the so called "fine dust pilots" included one (instead of two) farm locations. The measurements show that the system reduces the emission of fine particulate matter $\left(\mathrm{PM}_{10}\right)$ with $41 \%$.

Dit rapport is gratis te downloaden op https://doi.org/10.18174/518047 of op www.wur.nl/livestock-research (onder Wageningen Livestock Research publicaties).

(C) 2020 Wageningen Livestock Research

Postbus 338, 6700 AH Wageningen, T 03174839 53, E info.livestockresearch@wur.nl, www.wur.nl/livestock-research. Wageningen Livestock Research is onderdeel van Wageningen University \& Research.

Wageningen Livestock Research aanvaardt geen aansprakelijkheid voor eventuele schade voortvloeiend uit het gebruik van de resultaten van dit onderzoek of de toepassing van de adviezen.

Alle rechten voorbehouden. Niets uit deze uitgave mag worden vermenigvuldigd en/of openbaar gemaakt worden door middel van druk, fotokopie, microfilm of op welke wijze dan ook zonder voorafgaande toestemming van de uitgever of auteur.

Wageningen Livestock Research is NEN-EN-ISO 9001:2015 gecertificeerd.

Op al onze onderzoeksopdrachten zijn de Algemene Voorwaarden van de Animal Sciences Group van toepassing. Deze zijn gedeponeerd bij de Arrondissementsrechtbank Zwolle. 


\section{Inhoud}

$\begin{array}{ll}\text { Woord vooraf } & 5\end{array}$

$\begin{array}{ll}\text { Samenvatting } & 7\end{array}$

$\begin{array}{llr}1 & \text { Inleiding } & 8\end{array}$

$\begin{array}{lll}1.1 & \text { Wetenschappelijke probleembeschrijving } & 8\end{array}$

$\begin{array}{lll}1.2 & \text { Aanleiding } & 8\end{array}$

$\begin{array}{lll}1.3 & \text { Afbakening en doelstelling } & 9\end{array}$

$\begin{array}{lll}1.4 & \text { Opzet rapport } & 9\end{array}$

$2 \quad$ Materiaal en methoden $r$

$2.1 \quad$ Beschrijving techniek en werkingsprincipe 10

2.2 Beschrijving stal en bedrijfssituatie $\quad 11$

$\begin{array}{lll}2.3 \text { Meetstrategie } & 11\end{array}$

2.4 Meetmethoden 13

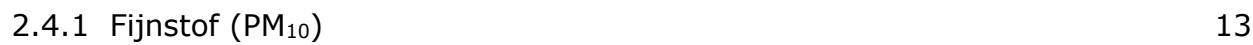

2.4.2 Ventilatiedebiet $\quad 13$

2.4.3 Temperatuur en relatieve luchtvochtigheid 13

2.4.4 Productiegegevens 14

2.5 Dataverwerking en analyse $\quad 14$

2.5.1 Berekening ventilatiedebiet $\quad 14$

2.5.2 Berekening fijnstofemissie 14

2.5.3 Berekening eindreductiepercentage fijnstofemissie met bandbreedte $\quad 15$

$\begin{array}{ll}2.5 .4 & \text { Statistische analyses }\end{array}$

$\begin{array}{llr}3 & \text { Resultaten } & 17\end{array}$

$\begin{array}{lll}3.1 & \text { Meetomstandigheden } & 17\end{array}$

$\begin{array}{lll}3.2 & \mathrm{CO}_{2} \text {-concentratie en ventilatiedebiet } & 19\end{array}$

$\begin{array}{ll}3.3 & \text { Concentratie, emissie en reductie } \mathrm{PM}_{10}\end{array}$

4 Discussie $r 2$

$\begin{array}{llr}5 & \text { Conclusie en advies } & 27\end{array}$

$\begin{array}{ll}\text { Literatuur } & 28\end{array}$

Bijlage 1 Beschrijving stal $\quad 30$

Bijlage 2 Landbouwkundige voorwaarden 35

Bijlage 3 Bepaling correctiefactor voor DustTrak model 853036

Bijlage $4 \quad$ Kalibratie meetapparatuur $\quad 37$

$\begin{array}{lll}\text { Bijlage } 5 & \text { Concept BWL-beschrijving } & 38\end{array}$ 



\section{Woord vooraf}

In de zoektocht voor pluimveebedrijven naar de mogelijkheden om de emissie van fijnstof ( $\left.P M_{10}\right)$ uit stallen terug te dringen is in de Regio Foodvalley een project bestaande uit een achttal pilots gestart. In de pilots kregen leveranciers van nieuwe technieken of stalsystemen de mogelijkheid om metingen te laten uitvoeren naar de effectiviteit daarvan. De pilots werden uitgevoerd onder de verantwoordelijkheid en organisatie van het Praktijkcentrum Emissiereductie Veehouderij (PEV). Pluimveehouders stelden voor de pilots hun stal beschikbaar als proeflocatie. Wageningen Livestock Research, tenslotte, leverde de wetenschappelijke kennis rondom veehouderijemissies en reductietechnieken, en voerde de metingen in de proefstallen uit. In dit rapport zijn de resultaten van de metingen aan een van de door het PEV geselecteerde technieken weergegeven. We willen de medewerkers van het PEV, het projectteam, de leverancier en de pluimveehouder bedanken voor de fijne en constructieve samenwerking bij de uitvoering van de metingen.

De auteurs 


\section{Samenvatting}

\section{Aanleiding en doel}

In sommige gebieden in Nederland, zoals in de Foodvalley regio, vormen pluimveestallen een belangrijke emissiebron van fijnstofdeeltjes $\left(\mathrm{PM}_{10}\right)$ in de buitenlucht die geassocieerd worden met gezondheidseffecten bij mensen. In deze pilot is onderzocht in welke mate de HD-ionisatielampen van de firma Freshlight in staat zijn om de emissie van fijnstof uit leghennenstallen te reduceren. Op basis van dit meetrapport kan de techniek worden opgenomen in nationale of regionale regelgeving met een (voorlopig) reductiepercentage voor fijnstof. Ondernemers in de veehouderij kunnen deze techniek vervolgens aanwenden op hun bedrijf om de belasting van de omgeving met fijnstof te verlagen.

\section{Fijnstofreductiesysteem en proefstal}

Aan het plafond van de stal hingen 3 rijen met elk $16 \mathrm{HD}$-ionisatielampen. De HD-ionisatielampen bestonden uit een led-TL en ionisatiedeel. Het ionisatiedeel produceert $300 * 10^{6}$ ionen per seconde met 12 koolstofborstels. Het ionisatiedeel verbruikt 2,4 watt. In deze leghennenstal waren 48 lampen aanwezig met ionisatiedeel, de ionenproductie was $16,8 * 10^{6}$ ionen per $\mathrm{m}^{2}$ staloppervlakte. De ionen die geproduceerd zijn veranderen de elektrische lading van stofdeeltjes. Volgens de leverancier bestaat het werkingsprincipe uit het binden van stofdeeltjes aan watermoleculen in de lucht en worden de deeltjes zwaarder, deze zwaardere deeltjes slaan neer op de grond. Het systeem maakt geen gebruik van ventilatie of recirculatie. Het systeem was geïnstalleerd in een gerenoveerde pluimveestal met 12.000 biologische leghennen.

\section{Meetstrategie en meetmethoden}

In dit onderzoek is een zogenaamde "case-control strategie in de tijd" gehanteerd. Dit betekent dat het systeem in principe de gehele productieperiode aan stond maar dat er tijdens elke meting eerst 24 uur gemeten werd met het systeem aan (case), gevolgd door een tweede periode van 24 uur terwijl het systeem uitgeschakeld was (control). Emissie reducerende technieken voor stallen worden normaliter getest volgens het meetprotocol zoals die is opgesteld in Nederland en in het internationale VERA collectief. Deze meetprotocollen zijn zo veel mogelijk gevolgd. In afwijking van de protocollen is er o.a. op één i.p.v. twee bedrijfslocaties gemeten. Geprobeerd werd de metingen gebalanceerd uit te voeren over de productieperiode en het kalenderjaar om een representatieve schatting van de reductie te verkrijgen waarbij invloeden van productiestadium en seizoen zijn meegenomen. De metingen betroffen: temperatuur en relatieve luchtvochtigheid, $\mathrm{CO}_{2}$-concentratie (t.b.v. het berekenen van het ventilatiedebiet middels de $\mathrm{CO}_{2}$-balansmethode) en concentratie van $\mathrm{PM}_{10}$. Uit de combinatie van ventilatiedebiet en $\mathrm{PM}_{10}$-concentratie is de $\mathrm{PM}_{10}$-emissie berekend.

\section{Resultaten}

In totaal werden zes metingen uitgevoerd, die allen gebruikt konden worden voor het bepalen van het reductiepercentage. Uit de statistische analyse bleek dat de staltemperatuur en het ventilatiedebiet niet significant verschilden tussen case- en controledagen wat duidt op een zuivere vergelijkingsbasis. De emissie van $\mathrm{PM}_{10}$ werd significant verlaagd met gemiddeld $41 \%$.

\section{Conclusie}

De HD-ionisatielampen van de firma Freshlight zijn in staat de emissie van $\mathrm{PM}_{10}$ in leghennenstallen te reduceren. Op grond van zes metingen aan één leghennenstal, waarbij de relevante meetprotocollen zoveel mogelijk zijn gevolgd, bedraagt deze reductie gemiddeld $41 \%$. Deze reductie is statistisch significant verschillend van nul. Rekening houdend met een onzekerheidsmarge van 10 procentpunten vanwege het meten op slechts één bedrijfslocatie, is het advies om een reductiepercentage op te nemen van $31 \%$. 


\section{$1 \quad$ Inleiding}

\subsection{Wetenschappelijke probleembeschrijving}

Fijnstof, oftewel $\mathrm{PM}_{10}$ is een verzamelnaam voor vaste en vloeibare deeltjes kleiner dan 10 micrometer $^{1}$ die zwevend in de lucht aanwezig zijn (EN 12341:2014; CEN, 2014). Na inademing kunnen deze zeer kleine deeltjes tot diep in de luchtwegen doordringen. Ze kunnen negatieve gezondheidseffecten veroorzaken, zoals een verhoogd risico op het ontstaan en verergeren van aandoeningen aan luchtwegen, longen, hart en bloedvaten. Fijnstof in de buitenlucht is verantwoordelijk voor circa $4 \%$ van de totale ziektelast. Na roken (13\%) behoort luchtverontreiniging daarmee tot één van de belangrijkste risicofactoren (Gezondheidsraad, 2018). Fijnstof is afkomstig van natuurlijke bronnen (zoals bosbranden, winderosie en zeezoutdeeltjes) en van antropogene bronnen zoals het verkeer en transport, de industrie en de agrarische sector. De Europese luchtkwaliteitsrichtlijn 2008/50/EG bevat grenswaarden voor o.a. fijnstof in de buitenlucht. De daggemiddelde concentratie mag maximaal $50 \mu \mathrm{g} / \mathrm{m}^{3}$ bedragen waarbij er jaarlijks maximaal 35 overschrijdingsdagen zijn toegestaan. Daarnaast mag de concentratie van fijnstof jaargemiddeld maximaal $40 \mu \mathrm{g} / \mathrm{m}^{3}$ bedragen. De World Health Organization hanteert een Air Quality Guideline limiet van jaargemiddeld een aanzienlijk lagere $20 \mu \mathrm{g} / \mathrm{m}^{3}$ (WHO, 2005). Er bestaat echter geen drempelwaarde voor de effecten van fijnstof, d.w.z. iedere in de lucht aanwezige microgram fijnstof is slecht voor de gezondheid.

De concentratie en samenstelling van fijnstof in de buitenlucht varieert van moment tot moment (temporele variatie) en van plek tot plek (spatiele variatie). In stedelijke gebieden kan circa tweederde van het in de buitenlucht aanwezige antropogene fijnstof afkomstig zijn van de uitstoot van verkeer en transport, terwijl in het agrarische buitengebied circa de helft van het in de lucht aanwezige antropogene fijnstof afkomstig kan zijn van stalemissies en landbouw (Hendriks et al., 2013). Stallen voor pluimvee, varkens en runderen vormen - na het verkeer en de industrie - de derde emissiebron van fijnstof in Nederland (Winkel et al., 2016). Deze deeltjes ontstaan in stallen vooral uit mest, veren, huid/haren, voer en stro(oisel) (Aarnink et al., 2011). Stalstof verschilt van stedelijk of industrieel stof doordat het van biologische origine is en rijk is aan micro-organismen en resten daarvan, zoals endotoxinen ${ }^{2}$ (Winkel et al, 2014). In Nederland is in de afgelopen jaren daarom gericht onderzoek gedaan naar de gezondheid van omwonenden van veehouderijen die blootstaan aan deze deeltjes. Dit betroffen achtereenvolgens de onderzoeksprojecten "Intensieve Veehouderij en Gezondheid" (Heederik en IJzermans, 2011), "Veehouderij en Gezondheid Omwonenden" (Maassen et al., 2016), "Veehouderij en Gezondheid Omwonenden II" (Hagenaars et al., 2017), "Veehouderij en Gezondheid Omwonenden III (IJzermans et al., 2018) en "Risicomodellering Veehouderij en Gezondheid" (Heederik et al, 2019). Uit deze onderzoeken blijkt dat de blootstelling aan stalstof en het endotoxine daarin geassocieerd is met minder atopie (gevoeligheid voor allergie). Aan de andere kant is de blootstelling geassocieerd met meer klachten en meer medicijngebruik bij omwonenden met $\mathrm{COPD}^{3}$, meer longontstekingen, meer klachten van de luchtwegen en een verlaagde longfunctie.

\section{$1.2 \quad$ Aanleiding}

In de Foodvalley regio, een regio van acht gemeenten ${ }^{4}$ met samen circa 350.000 inwoners, komen relatief hoge concentraties voor van fijnstof, ammoniak $\left(\mathrm{NH}_{3}\right)$ en geur door de aanwezigheid van veel veehouderijbedrijven. Naar aanleiding van de resultaten van de hiervoor genoemde onderzoeken naar de effecten van veehouderijen op de gezondheid van omwonenden zijn in de Regio Foodvalley afspraken gemaakt tussen regionale overheden en de veehouderijsector om de bijdrage van de

\footnotetext{
${ }^{1}$ Eén micrometer $(\mu \mathrm{m})$ is gelijk aan één duizendste millimeter, $10 \mu \mathrm{m}$ is gelijk aan een honderdste millimeter.

2 Endotoxinen zijn celwanddelen van Gram-negatieve bacteriën die sterk ontstekingsbevorderend zijn.

${ }^{3}$ COPD: Chronic Obstructive Pulmonary Disease = Chronische Obstructieve Long Aandoeningen.

${ }^{4}$ De acht gemeenten in de Foodvalley regio zijn: Barneveld, Ede, Nijkerk, Rhenen, Renswoude, Scherpenzeel, Veenendaal en Wageningen.
} 
veehouderij op de luchtkwaliteit in de regio te verminderen. Deze samenwerking is vastgelegd in het Manifest Gezonde Leefomgeving Veehouderij (GLV). De afspraken in het Manifest omvatten grofweg twee sporen:

- Bestuurlijk: optimalisatie/kansen benutten binnen vergunningverlening, scenarioberekeningen, afstemming en aanpassing regelgeving rijksoverheid.

- Praktijk: kennis verzamelen en delen over emissiereducties van technieken en stalsystemen, innovaties bevorderen en faciliteren, meetmethodes en -strategieën testen en verbeteren.

Binnen de 'praktijk-route' is het Praktijkcentrum Emissiereductie Veehouderij (PEV) opgericht waarmee de betrokkenen van het Manifest GLV versneld willen werken aan het ontwikkelen en praktijkrijp brengen van haalbare en betaalbare emissie reducerende technieken en stalsystemen die nog niet beschikbaar zijn in de Lijst Emissiefactoren fijn stof voor veehouderij (Rijksoverheid, 2018).

Hoewel het PEV zich wil richten op het verminderen van emissies van alle vormen van luchtverontreiniging uit stallen, is er in eerste instantie gekozen om de aandacht te richten op technieken die de emissie van fijnstof reduceren. Hiertoe is een traject opgestart waarbij innoverende leveranciers van technieken hun systeem aan konden melden met daarbij relevante informatie over o.a. het werkingsprincipe, het verwachte reductiepercentage en de jaarkosten voor veehouders. Via een selectieprocedure zijn acht technieken geselecteerd die op veehouderijbedrijven zijn geïnstalleerd om het effect daarvan op de emissie van $\mathrm{PM}_{10}$ vast te stellen. In dit rapport wordt van één van deze technieken het resultaat van de metingen gepresenteerd.

\subsection{Afbakening en doelstelling}

Dit meetrapport bevat de resultaten van de emissiemetingen gedaan in de pilot met de HDionisatielampen van de firma Freshlight, geïnstalleerd in een leghennenstal. Emissie reducerende technieken voor stallen worden normaliter getest volgens het meetprotocol zoals die is opgesteld in Nederland (Ogink et al., 2011) en in het internationale VERA collectief (VERA, 2018a). In de pilots is op een aantal punten afgeweken van deze protocollen om met beperkte inspanningen en kosten toch een goede eerste indruk te krijgen van het reductiepotentieel van een techniek. De onzekerheden die de omissies t.a.v. de protocollen met zich meebrengen worden in de discussie van dit rapport beoordeeld. Op basis van dit meetrapport kan de techniek worden opgenomen in nationale of regionale regelgeving met een (voorlopig) reductiepercentage voor fijnstof. Ondernemers in de veehouderij kunnen deze techniek vervolgens aanwenden op hun bedrijf om de belasting van de omgeving met stalstof te verlagen.

\section{$1.4 \quad$ Opzet rapport}

Zoals gebruikelijk in een meetrapport wordt in hoofdstuk 2 ingegaan op de toegepaste materialen en methoden. Daarbij wordt eerst de techniek waar de metingen zich op richtten beschreven, samen met het werkingsprincipe. Daarna volgt een korte beschrijving van de stal waarin de techniek is toegepast. Tot slot worden de gebruikte meetmethoden en de meetstrategie beschreven en de verwerking van de meetgegevens. In hoofdstuk 3 worden de resultaten van de metingen gepresenteerd, waarna in hoofdstuk 4 een discussie volgt over de aspecten die mogelijk van invloed zijn geweest op de techniek en over in hoeverre de resultaten gebruikt kunnen worden voor opname in de (nationale) regelgeving. De conclusie naar aanleiding van de discussie volgt daarna in hoofdstuk 5. 


\section{Materiaal en methoden}

\subsection{Beschrijving techniek en werkingsprincipe}

Aan het plafond van de stal hingen 3 rijen met elk 16 HD-ionisatielampen. De HD-ionisatielampen bestaan uit een LED-TL en een ionisatiedeel. Het ionisatiedeel produceert $300 * 10^{6}$ ionen per seconde met 12 koolstofborstels. Het ionisatiedeel verbruikt 2,4 watt. In deze leghennenstal waren 48 lampen aanwezig met ionisatiedeel, de ionenproductie was $16,8 * 10^{6}$ ionen per seconde per $\mathrm{m}^{2}$ vloeroppervlak. Volgens de leverancier bestaat het werkingsprincipe uit het veranderen van de elektrische lading van stofdeeltjes zodat deze zich aan andere stofdeeltjes en watermoleculen in de lucht binden. De stofdeeltjes worden hierdoor zwaarder, deze zwaardere deeltjes slaan neer op de grond. Het systeem maakt geen gebruik van ventilatie of recirculatie (Freshlight, 2019). Figuur 2.1-A geeft een foto van een ionisatielamp. Figuur 2.1-B geeft een weergave van de techniek zoals toegepast in de proefstal waarin is gemeten.

In bijlage 6 is een concept van de beschrijving opgenomen, conform het format van de BWLbeschrijvingen voor reducerende technieken. Hierin zijn de belangrijkste elementen waaraan een stal uitgerust met deze techniek moet voldoen om een vergelijkbaar effect op de stofemissie te realiseren.

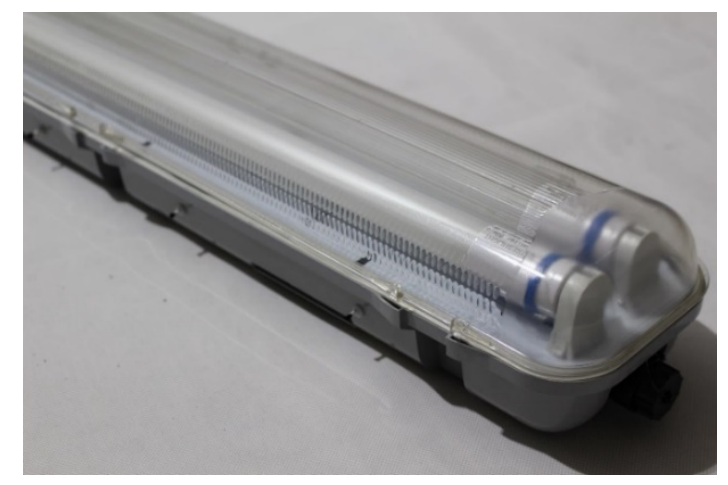

Figuur 2.1-A Foto van de HD-ionisatielamp.

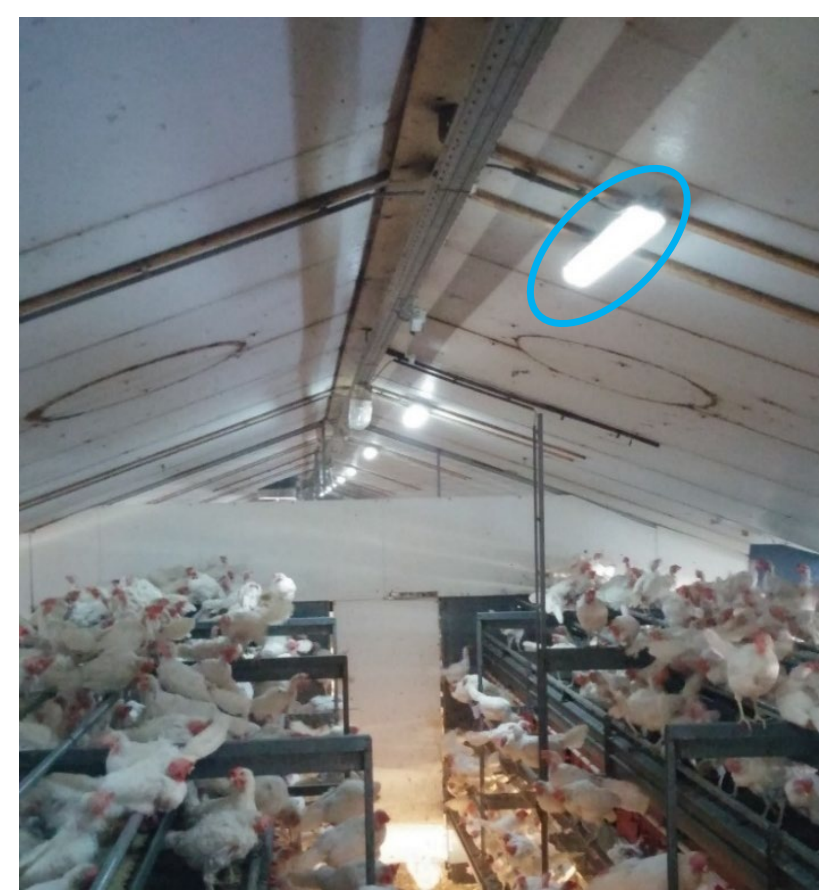

Figuur 2.1-B De HD-ionisatielampen in de stal waar is gemeten. Op de foto is één ionisatielamp blauw omcirkeld. 


\subsection{Beschrijving stal en bedrijfssituatie}

De metingen zijn uitgevoerd in een stal voor leghennen. In de stal werden 12.000 biologische leghennen gehouden, verdeeld over vier compartimenten (zie ook figuur 2.1-B). De kippen waren gehuisvest in twee systeemrijen met bijbehorend drie strooiselgangen. Voor de ventilatie van de stal werd gebruik gemaakt van vier nokventilatoren (in elk compartiment één). De lucht kwam de stal binnen via inlaten in beide zijwanden. In de stal waren drie rijen met elk 16 HD-ionisatielampen aanwezig, één rij door het midden van de stal en twee aan de buitenkanten om de gehele stal te verlichten (zie figuur 2.1-B). Aan de noordzijde is de stal voorzien van een inpandige overdekte uitloop van waaruit de leghennen ook naar buiten konden. Tijdens de metingen is deze buiten gebruik gesteld. In bijlage 1 is een overzicht opgenomen van de belangrijkste kenmerken van de stal en enkele managementaspecten, samen met enkele foto's, een stalplattegrond en een overzichtsfoto van het bedrijf. Op deze overzichtsfoto is te zien dat er in zuidelijke richting nog een andere stal op het bedrijf aanwezig is ten opzichte van de gemeten stal, dit is een opfok leghennenstal. In de verdere omgeving zijn andere agrarische bedrijven aanwezig, waaronder pluimveebedrijven.

\section{$2.3 \quad$ Meetstrategie}

Emissie reducerende technieken voor stallen worden normaliter getest volgens het meetprotocol zoals die is opgesteld in Nederland (Ogink et al., 2011) en in het internationale VERA collectief (VERA, 2018a). Deze protocollen schrijven o.a. het volgende voor:

- een techniek moet op twee bedrijfslocaties wordt getest om variatie in de prestatie van de techniek tussen bedrijven (t.g.v. ras, management, voeding, enzovoort) mee te nemen in het uiteindelijke reductiepercentage;

- de metingen dienen plaats te vinden in een proefstal versus een identieke referentiestal op hetzelfde bedrijf (een "case-control" strategie) of ná versus vóór een end-of-pipe-techniek zoals een filter;

- per bedrijfslocatie moeten er zes 24-uursmetingen uitgevoerd worden (totaal 12). Daarvan moeten tenminste vier metingen per bedrijfslocatie en tien in totaal betrouwbare resultaten opleveren. Door metingen over 24 uur uit te voeren wordt alle variatie die er binnen een dag optreedt meegenomen in de resultaten. De metingen moeten worden gespreid over het kalenderjaar en de productieperiode van de dieren om ook variatie t.g.v. seizoenen en productiestadia van dieren mee te nemen in de resultaten;

- de emissie bestaat uit het product van ventilatiedebiet maal concentratie van een vervuilende stof. Het protocol schrijft zowel voor het meten van het ventilatiedebiet als voor het meten van concentraties een aantal wetenschappelijk valide meetmethoden voor. Voor pluimveestallen waar meerdere ventilatoren aanwezig zijn (wat het gebruik van meetwaaiers belemmert) is de $\mathrm{CO}_{2}$ balansmethode een valide methodiek om het ventilatiedebiet te bepalen. Voor fijnstof schrijft het Nederlandse fijnstofprotocol een gravimetrische methode voor die geschikt is voor toepassing in een stofrijke stalomgeving;

- de bemeten stallen dienen te voldoen aan landbouwkundige randvoorwaarden, zie bijlage 2 . Hierin staat opgenomen welke bedrijfsparameters tijdens het uitvoeren van de metingen dienen te worden geregistreerd en gerapporteerd, om naderhand te kunnen verifiëren of de metingen hebben plaatsgevonden onder representatieve omstandigheden.

Gezien de grote behoefte aan innovatieve technieken voor fijnstofreductie in de pluimveehouderij is in de fijnstofpilots in de Foodvalley regio beoogd om op een relatief goedkope en eenvoudige manier snel inzicht te krijgen in het perspectief en de reductie van zulke technieken. Daarom zijn er in de pilots een aantal bewuste omissies gepleegd t.a.v. de methodologie. Deze kunnen als volgt worden samengevat:

a. de gemiddelde emissiereductie is vastgesteld door een meetserie van zes metingen op één bedrijfslocatie i.p.v. twee meetseries van in totaal twaalf metingen op twee bedrijfslocaties zoals het meetprotocol dit voorschrijft;

b. Er is niet gemeten in een fysieke proefstal en een fysieke controlestal maar gemeten volgens een "case-control in de tijd" strategie. Een techniek wordt dan in een proefstal geïnstalleerd waarbij via metingen tijdens aan-dagen versus uit-dagen het reductiepercentage wordt bepaald; 
c. de concentraties en emissies van fijnstof $\left(\mathrm{PM}_{10}\right)$ zijn vastgesteld met DustTraks (een lichtverstrooiingsmethode) in plaats van met een gravimetrische meetmethode;

d. het ventilatiedebiet is vastgesteld aan de hand van de $\mathrm{CO}_{2}$-balansmethode op grond van metingen van $\mathrm{CO}_{2}$ in de stal (conform het meetprotocol) maar met een vaste (niet gemeten) achtergrondwaarde voor $\mathrm{CO}_{2}$ in de buitenlucht;

e. de achtergrondconcentraties van fijnstof $\left(\mathrm{PM}_{10}\right)$ zijn niet gemeten, hiervoor zijn achtergrondconcentraties gebruikt van het dichtstbijzijnde meetstation van het Luchtmeetnet (RIVM, 2019).

Er zijn in totaal zes metingen uitgevoerd, die allen bruikbare resultaten opleverden. Metingen zijn uitgevoerd gedurende ca. 24 uur. Gedurende de onderzoeksperiode heeft de reducerende techniek in de stal normaal gesproken op 'aan' gestaan. Tijdens de eerste metingen is eerst 24 uur gemeten met de techniek aan, waarna aan het eind van de meting de techniek op 'uit' is gezet. Na een stabilisatieperiode van minimaal 24 uur is gedurende 24 uur gemeten met de techniek uit. In een later stadium zijn de case- en controledagen omgedraaid. De pluimveehouder heeft daarbij 24 uur voor de aanvang van de 'uit'-meting de techniek uitgeschakeld. Na deze 24 uur is de 'uit'-meting gestart en heeft de pluimveehouder de techniek na 24 uur weer ingeschakeld waarbij de meting doorliep en overging in de 'aan'-meting. De 'aan'-meting is daarna minimaal 25 uur voortgezet, waarbij het eerste uur als een stabilisatieperiode werd gezien en niet is meegenomen in de verwerking van de data. Volgens de leverancier is een uur stabilisatieperiode tussen de uit- en de aan-meting voldoende om het effect van de ionisatielampen te kunnen meten. De reden voor deze wijziging in de meetstrategie was dat er bij de eerste metingen grote verschillen waren in buitenklimaat tussen case- en controledagen dat zich mogelijk vertaalt in verschillende ventilatiedebieten en daarmee een minder zuivere vergelijkingsbasis tussen de twee dagen. Om een reductie van de emissie zo zuiver mogelijk te kunnen toeschrijven aan de werking van de reducerende techniek zijn de meetdagen dichter bij elkaar gekozen; met een kleinere kans op grote verschillen in buitenklimaat.

Tijdens voornoemde meetdagen zijn de concentraties van fijnstof $\left(\mathrm{PM}_{10}\right)$ en koolstofdioxide $\left(\mathrm{CO}_{2}\right)$ gemeten, alsook de temperatuur en relatieve luchtvochtigheid (RV). Met behulp van gasdetectiebuisjes (Kitagawa) is op iedere meetdag indicatief de ammoniakconcentratie gemeten. Er zijn geen concentraties van fijnstof, dan wel waarden van temperatuur en RV gemeten in de buitenlucht. Voor deze waarden is gebruik gemaakt van de dichtstbijzijnde meetstations van het KNMI (voor temperatuur en RV, locatie: de Bilt) en het RIVM (voor PM10, locatie: Wekerom-Riemterdijk) voor dezelfde periode als de meetperioden. Voor de concentratie van $\mathrm{CO}_{2}$ in de buitenlucht is een vaste waarde van 400 ppm genomen.

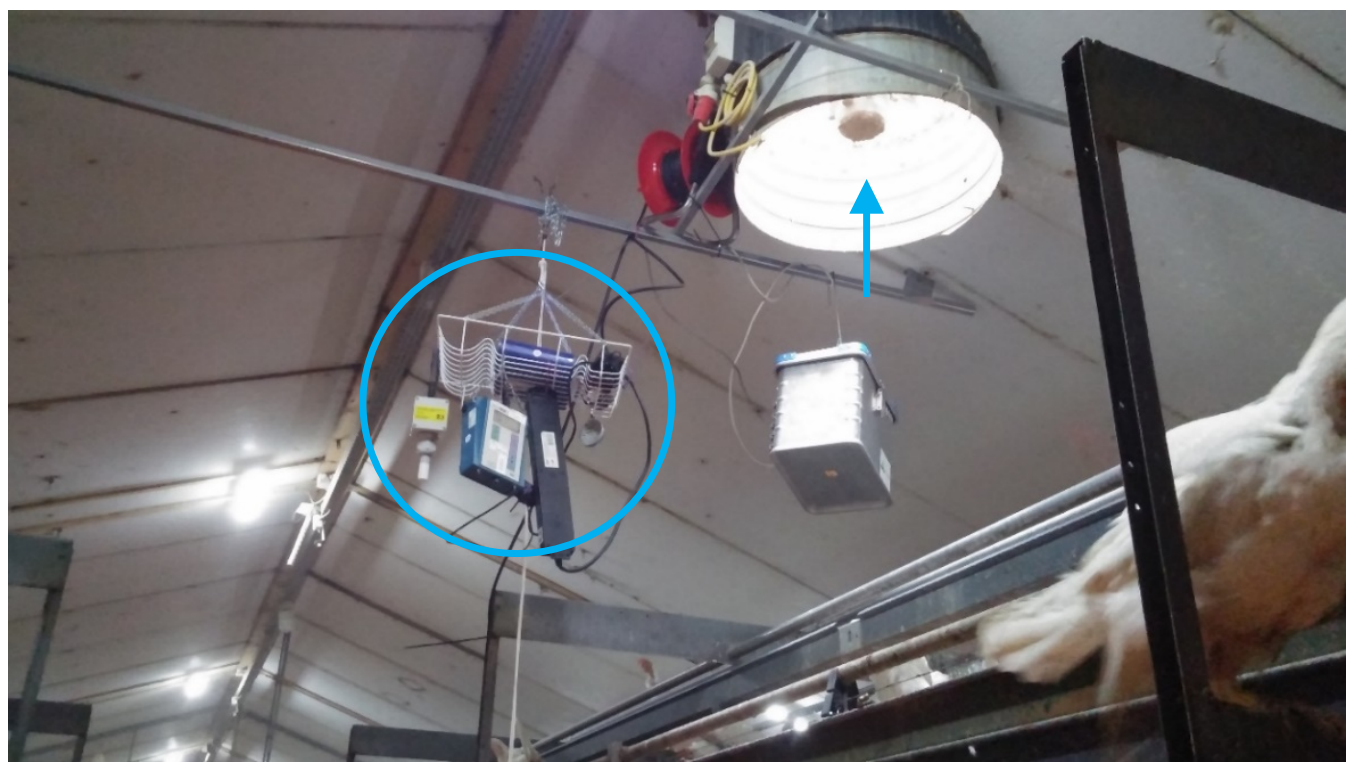

Figuur 2.2 Plaats van de meting van de concentraties in de stal (blauw omcirkeld). De blauwe pijl geeft de luchtstroom aan de ventilatiekoker in, naar buiten toe. 
Voor het bepalen van de concentraties in de uitgaande luchtstroom is een positie gekozen zo dicht mogelijk bij de ventilatoren die zorgen voor de afvoer van de stallucht, zodanig dat de luchtsnelheid beneden $2 \mathrm{~m} / \mathrm{s}$ bleef om niet-isokinetische condities (d.w.z. condities waarbij de luchtsnelheid in de stal en die van de sample flow te zeer uit de pas lopen en grotere deeltjes onder- of overbemonsterd worden) te voorkomen. Figuur 2.2 geeft de situatie in de bemeten stal weer van de meetpositie ten opzichte van de ventilatoren. In bijlage 1 is het meetpunt in de stal blauw omcirkeld.

\subsection{Meetmethoden}

Een omschrijving van het onderhoud en kalibraties van onderstaande instrumenten is te vinden in bijlage 4 .

\subsubsection{Fijnstof $\left(\mathrm{PM}_{10}\right)$}

De concentratie van fijnstof $\left(\mathrm{PM}_{10} ; \mathrm{mg} / \mathrm{m}^{3}\right)$ is in duplo gemeten met een DustTrak apparaat (DustTrak ${ }^{\mathrm{TM}}$ Aerosol Monitor, modellen 8520 en 8530, TSI Inc., Shoreview, USA; zie voor beide modellen figuur 2.3). De $\mathrm{PM}_{10}$-concentratie werd elke seconde gemeten en als tweeminutengemiddelden gelogd in het geheugen van de DustTraks. De DustTraks geven een systematische onderschatting van de echte concentratie (zoals bepaald volgens CEN-EN 12341; Winkel et al., 2015a; Cambra-López et al., 2013). Daarom zijn de concentraties, zowel van proef- als referentieperioden, gecorrigeerd met een correctiefactor. Voor de metingen uitgevoerd met model 8520 is dat de factor 2,14 zoals gepubliceerd door Winkel et al. (2015a) en Cambra-López et al. (2013). Voor de metingen uitgevoerd met model 8530 is dat de factor 2,53 die door WLR is bepaald op dezelfde wijze als is gedaan in Winkel et al. (2015a). De resultaten van de metingen die ten grondslag liggen aan deze correctiefactor staan in bijlage 3.
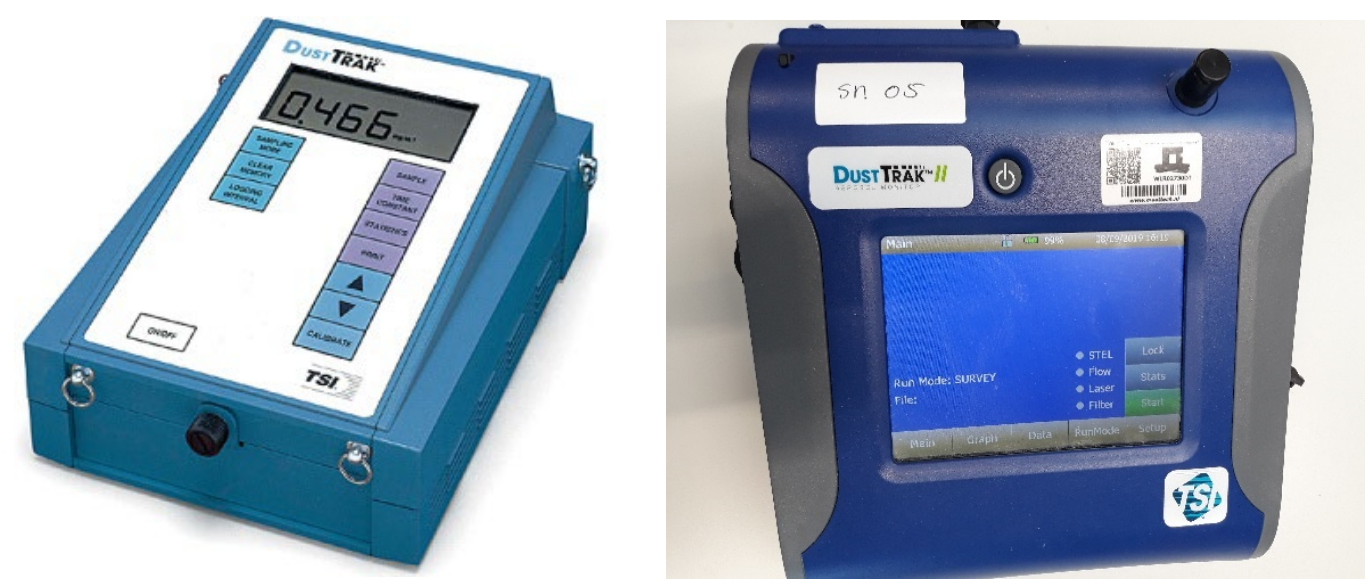

Figuur 2.3 Gebruikte DustTrak-modellen voor het meten van PM10. Links model 8520, rechts model 8530 .

\subsubsection{Ventilatiedebiet}

Ten behoeve van het vaststellen van het ventilatiedebiet is de concentratie van koolstofdioxide $\left(\mathrm{CO}_{2}\right)$ gemeten. Via de $\mathrm{CO}_{2}$-balansmethode is het ventilatiedebiet bepaald. De $\mathrm{CO}_{2}$-concentratie in de uitgaande stallucht is gemeten met behulp van een Testo $\mathrm{CO}_{2}$-meter (Testo B.V.; Almere, Nederland; type 435, met IAQ-probe voor $\mathrm{CO}_{2}$ ) of een Vaisala $\mathrm{CO}_{2}$-sensor (Vaisala; Vantaa, Finland; CARBOCAP ${ }^{\circledR}$ Carbon Dioxide Probe GMP252; type met meetbereik 0-5000 ppm).

\subsubsection{Temperatuur en relatieve luchtvochtigheid}

Ter vastlegging van de meetomstandigheden werden temperatuur en relatieve luchtvochtigheid gemeten met een gecombineerde logger (Escort iLog; Askey dataloggers; Leiderdorp, Nederland). 


\subsubsection{Productiegegevens}

Op iedere tweede dag van de metingen is de volgende informatie overgenomen van de hokkaart:

- aantal opgezette en aanwezige dieren;

- indien mogelijk: gemiddeld diergewicht (eventueel afgelezen waarde voor het betreffende productiestadium uit de productiegids van het merk dier);

- voerverbruik van de dieren;

- waterverbruik van de dieren;

- legpercentage;

- eigewicht;

- uitval;

- eventuele toediening van medicatie of additieven.

\subsection{Dataverwerking en analyse}

\subsubsection{Berekening ventilatiedebiet}

Voor het berekenen van het ventilatiedebiet per afzonderlijke meetdag is de $\mathrm{CO}_{2}$-balansmethode gebruikt. Deze methode is gebaseerd op de rekenregels van de CIGR voor het bepalen van de $\mathrm{CO}_{2}$ productie van de dieren (CIGR, 2002; Pedersen et al., 2008). Hiervoor wordt eerst de warmteproductie van de leghennen als volgt berekend:

$$
\Phi_{\text {tot }}=6.8 m^{0.75}+25 Y_{2}
$$

waarbij:

- $\Phi_{\text {tot }}=$ totale warmteproductie per dier in $\mathrm{W}$;

- $\mathrm{m}=$ gewicht van het dier in $\mathrm{kg}$

- $\mathrm{Y}_{2}=$ eiproductie in $\mathrm{kg} / \mathrm{dag}$.

De $\mathrm{CO}_{2}$-productie werd vervolgens berekend met behulp van de volgende formule:

$$
\mathrm{CO}_{2}-\text { productie }=\Phi_{\text {tot }} * 0.185
$$

waarbij:

- $\mathrm{CO}_{2}$-productie = productie van $\mathrm{CO}_{2}$ in $\mathrm{m}^{3} /$ uur per dier;

- 0.185 = waarde voor $\mathrm{CO}_{2}$-productie per $\mathrm{kW}$ in $\mathrm{m}^{3} / \mathrm{uur}$ per dier.

Het ventilatiedebiet werd vervolgens berekend op basis van de volgende formule:

$$
\mathrm{Q}=\frac{\mathrm{CO}_{2}-\text { productie }}{\left(\left[\mathrm{CO}_{2}\right]_{\text {stal }}-\left[\mathrm{CO}_{2}\right]_{\text {buiten }}\right) * 10^{-6}}
$$

waarbij:

- $\mathrm{Q}=$ ventilatiedebiet in $\mathrm{m}^{3} / \mathrm{uur}$ per dier;

- $\left[\mathrm{CO}_{2}\right]_{\text {stal }}=\mathrm{CO}_{2}$ concentratie in parts per million $(\mathrm{ppm})$ gemeten bij het emissiepunt van de stal;

- $\left[\mathrm{CO}_{2}\right]_{\text {buiten }}=$ vaste waarde voor de concentratie van $\mathrm{CO}_{2}$ van $400 \mathrm{ppm}$.

\subsubsection{Berekening fijnstofemissie}

Per afzonderlijke meetdag werd de emissie van $\mathrm{PM}_{10}$ bepaald, d.w.z. zowel voor de 'referentiedagen' als de 'proefdagen' binnen de proefstal, op basis van de volgende formule:

$$
E=\mathrm{Q} *\left(\left[P M_{10}\right]_{\text {stal }}-\left[P M_{10}\right]_{\text {buiten }}\right) * 10^{-6} * 24 * 365
$$

waarbij:

- $\mathrm{E}=$ emissie van $\mathrm{PM}_{10}$ in $\mathrm{g} / \mathrm{jaar}$ per aanwezig dier;

- $\mathrm{Q}=$ ventilatiedebiet in $\mathrm{m}^{3} / \mathrm{uur}$ per dier;

- $\left[\mathrm{PM}_{10}\right]_{\text {stal }}=$ de concentratie van $\mathrm{PM}_{10}$ in $\mu \mathrm{g} / \mathrm{m}^{3}$, gemeten nabij het emissiepunt van de stal; 
- $\left[\mathrm{PM}_{10}\right]_{\text {buiten }}=$ de concentratie van $\mathrm{PM}_{10}$ in $\mu \mathrm{g} / \mathrm{m}^{3}$, gemeten door het dichtstbijzijnde meetstation van het Landelijk Meetnet Luchtkwaliteit voor dezelfde periode;

- $10^{-6}=$ conversiefactor van $\mu \mathrm{g}$ naar $\mathrm{g}$;

- 24 = conversiefactor van uur naar dag;

- 365 = conversiefactor van dag naar jaar.

Er wordt in bovenstaande berekening geen rekening gehouden met de leegstand tussen productieperioden. Dit is wel nodig bij het berekenen van een absolute emissiefactor, maar niet in deze situatie voor het berekenen van een reductiepercentage.

\subsubsection{Berekening eindreductiepercentage fijnstofemissie met bandbreedte}

In de pilot was sprake van de volgende situatie:

- leghennen met een stabiel emissiepatroon;

- meetdagen die gebalanceerd zijn gekozen over de productieperiode en het jaar.

In deze situatie is het eindreductiepercentage berekend over de emissies. Door eerst de emissies van casedagen en controledagen te middelen en vervolgens een eindreductiepercentage te berekenen over die twee gemiddelde emissiecijfers worden de individuele reductiepercentages gewogen naar rato van hun bijdrage aan de totale emissie.

Om enig inzicht te krijgen in de precisie waarmee het verkregen eindreductiepercentage is bepaald, zijn voor dit cijfer een aantal betrouwbaarheidsintervallen berekend. Een $\mathrm{x} \%$-betrouwbaarheidsinterval is een combinatie van een ondergrens en bovengrens waarvoor het voor $\mathrm{x} \%$ zeker is dat het gemiddelde daarin valt. Hiervoor zijn de reductiepercentages van de individuele metingen gebruikt. Onder de aanname van statistische onafhankelijkheid en normaliteit geldt dat het betrouwbaarheidsinterval gelijk is aan het gemiddelde $\pm t_{(v=n-1 ; \alpha)} * \mathrm{SE}$, waarbij $t$ de waarde is uit de Student-verdeling bij $v$ vrijheidsgraden, $n$ waarnemingen en een onbetrouwbaarheidsdrempel $\alpha$ en SE de standaardfout (berekend als de standaardafwijking gedeeld door de wortel uit het aantal waarnemingen).

\subsubsection{Statistische analyses}

Verschillen tussen case- en controledagen voor de variabelen die direct of indirect gerelateerd zijn aan het emissieproces, zijn getoetst op significantie door middel van gepaarde $t$-toetsen. Het gaat daarbij om de factoren:

- temperatuur in de stal;

- relatieve luchtvochtigheid in de stal;

- $\mathrm{CO}_{2}$-concentratie in de stal;

- ventilatiedebiet;

- fijnstofconcentratie in de stal, en;

- fijnstofemissie.

De eerste vier genoemde variabelen zijn tweezijdig getoetst. De laatste twee genoemde variabelen zijn eenzijdig getoetst, uitgaande van de onderzoekshypothese van hogere waarden op controledagen.

De vergelijkbaarheid van het ventilatiedebiet op case-dagen versus die op controledagen werd verkend met behulp van Enkelvoudige Lineaire Regressie. Hierbij wordt het ventilatiedebiet op casedagen als $\mathrm{Y}$-variabele genomen en het ventilatiedebiet op controledagen als $\mathrm{X}$-variabele. Idealiter ontstaat tussen de twee variabelen een $Y=x$ oftewel $1: 1$ relatie met een lijnstuk door de oorsprong onder een hoek van 45 graden omhoog. Getoetst is of de richtingscoëfficiënt significant afwijkt van 1 (bij standaard regressie wordt getoetst op afwijken van nul).

Relaties tussen het reductiepercentage en mogelijke invloedsfactoren (fijnstofconcentratie, ventilatiedebiet) op de effectiviteit van de techniek werden verkend met behulp van Enkelvoudige Lineaire Regressie. Hier is een effect van de invloedsfactor (X-variabele) op het reductiepercentage ( $Y$ variabele) verkend door te toetsen of de richtingscoëfficiënt significant afwijkt van nul. 
Voor de analyses werden de paartjes van waarnemingen als statistisch onafhankelijk beschouwd. Verschillen of relaties werden als statistisch significant beschouwd bij een P-waarde <0,05 en als trendmatig bij een $\mathrm{P}$-waarde tussen 0,05 en 0,10. Alle analyses werden uitgevoerd met behulp van het statistische programma GenStat (VSN, 2019). 


\section{Resultaten}

\subsection{Meetomstandigheden}

Het Nederlandse meetprotocol voor fijnstof (Ogink et al., 2011) schrijft voor dat er per bedrijfslocatie zesmaal gemeten moet worden. De metingen moeten gelijkmatig verdeeld over een jaar zijn verricht. Figuur 3.1 laat zien hoe de metingen op de locatie in werkelijkheid verdeeld waren. Minimaal $80 \%$ van de metingen moet betrouwbare resultaten opleveren. De metingen zijn gebalanceerd over de productieperiode uitgevoerd.
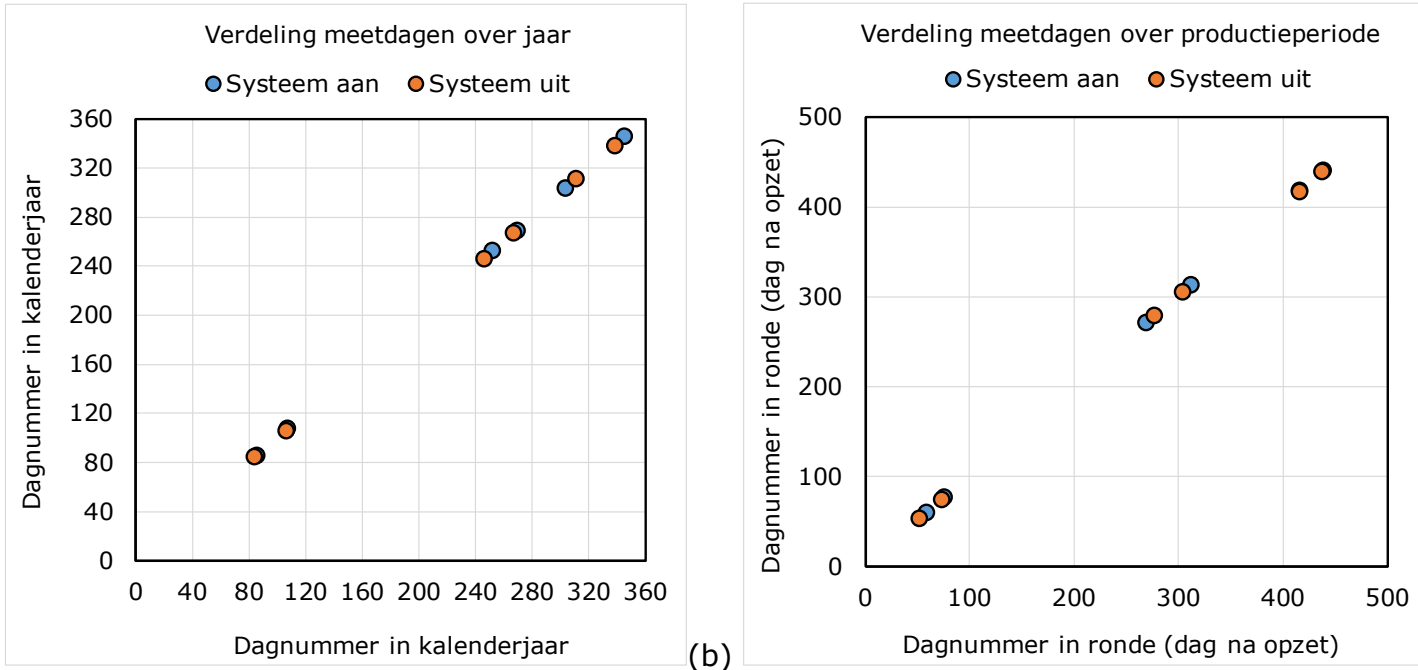

(a)

(b)
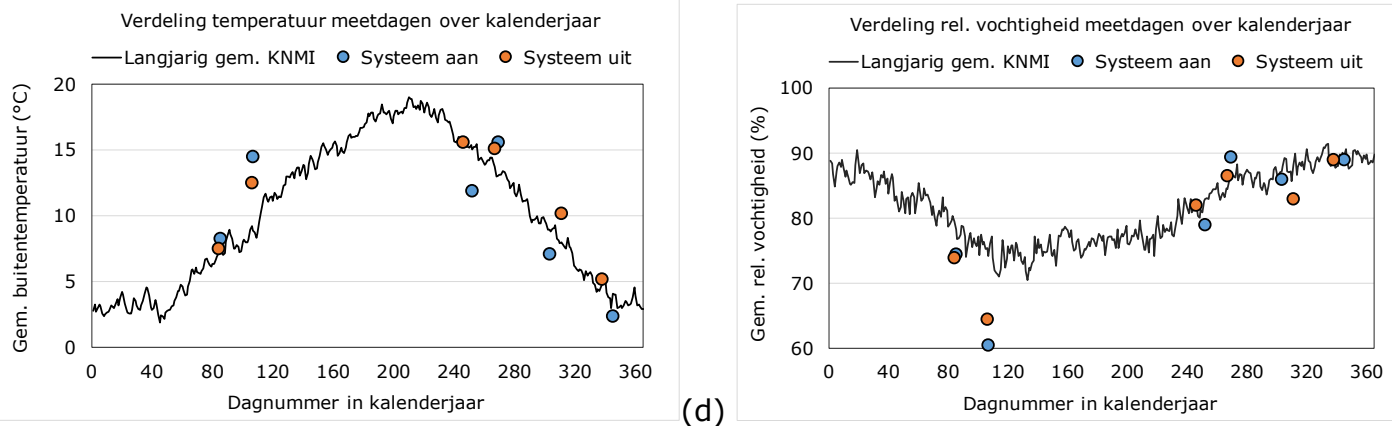

Figuur 3.1 Verdeling van de metingen over het jaar (a), en productieperiode (b) en in vergelijking met de buitentemperatuur (c) en relatieve luchtvochtigheid (d) volgens de gemiddelde waarden gemeten over 1981 t/m 2010 van het KNMI-station De Bilt (weergegeven als lijn).

Er zijn in totaal zes metingen uitgevoerd in de periode oktober 2018 tot en met september 2019. Hiervan gaven alle metingen betrouwbare resultaten.

Het gemiddelde dagnummer van de dagen waarop is gemeten is 226 (streven: ca 183). De metingen zijn niet geheel gelijkmatig over het jaar verdeeld. Twee metingen vallen in het voorjaar en vier metingen in het najaar. Er zijn geen metingen in de winter en zomer uitgevoerd en minder metingen in de eerste helft van het jaar. Reden voor deze verdeling is o.a. de looptijd van het project, niet kunnen inzetten van meettechnici door ziekte, dreiging van aviaire influenza en de fipronilcrisis (door de laatste twee redenen waren bedrijfsbezoeken in sommige periodes niet mogelijk).

In tabel 1 zijn o.a. de data waarop de metingen zijn uitgevoerd met de relevante technische resultaten en klimaatomstandigheden (buiten en binnen in de stal) weergegeven. De technische resultaten van de dieren (wateropname, voeropname, water/voer-verhouding, productie, en uitval) vielen bijna allemaal binnen de normen van het ras die gesteld zijn door de fokkerijgroepering en de 
landbouwkundige voorwaarden. Het hogere uitvalspercentage ten opzichte van de landbouwkundige voorwaarden wordt verklaard doordat gemeten is bij biologische leghennen. Het uitvalspercentage bij deze productiewijze ligt standaard hoger dan bij reguliere hennen. Verder zijn er geen afwijkingen van geweest van het standaard bedrijfsmanagement.

Voor de klimaatgegevens voor de buitenlucht (temperatuur en RV) zijn de gegevens gebruikt van het meetstation in De Bilt. De gemiddelde buitentemperatuur bedroeg $10,0^{\circ} \mathrm{C}$ voor de meetdagen met de techniek aan versus $11,0^{\circ} \mathrm{C}$ voor de meetdagen met de techniek uit (langjarig gemiddelde KNMI: $10,2^{\circ} \mathrm{C}$ ). Voor de RV was dit op beide meetdagen $80 \%$ (langjarig gemiddelde KNMI: $82 \%$ ). De gemiddelde buitentemperatuur tijdens de metingen lag daarmee slechts $0,2{ }^{\circ} \mathrm{C}$ lager en $0,8^{\circ} \mathrm{C}$ hoger dan het langjarig gemiddelde voor respectievelijk meetdagen met de techniek aan en uit. Dit komt voornamelijk doordat metingen zijn uitgevoerd in het voor- en najaar. De gemiddelde RV tijdens de meetdagen lag slechts twee procentpunten onder het langjarig gemiddelde.

De gemiddelde temperatuur in de stal bedroeg $21,9^{\circ} \mathrm{C}$ voor de meetdagen met de techniek aan versus $23,1^{\circ} \mathrm{C}$ voor de meetdagen met de techniek uit. Uit de statistische analyse bleek een trendmatig lagere temperatuur voor meetdagen met de techniek aan $(P=0,09)$. De gemiddelde relatieve luchtvochtigheid in de stal bedroeg $58,3 \%$ voor de meetdagen met de techniek aan versus $58,9 \%$ voor de meetdagen met de techniek uit. Uit de statistische analyse bleek dit verschil niet statistisch significant $(P=0,84)$. Kennelijk zijn de meetdagen met de techniek uit gemiddeld iets warmer geweest. Het verschil is statistisch slechts licht trendmatig, daarom berust dit waarschijnlijk op toeval.

De waarden van de indicatieve $\mathrm{NH}_{3}$-metingen zijn niet opgenomen in tabel 3.1. Ze varieerden binnen de normale waarden voor stallen met leghennen en geven geen aanleiding om een relatie met de HDionisatielampen te analyseren.

Tabel 1 Data warop de metingen zijn uitgevoerd met dagnummer in het jaar en dagnummer in productiecyclus, relevante technische resultaten en de klimaatomstandigheden (buitenklimaat en in de stal).

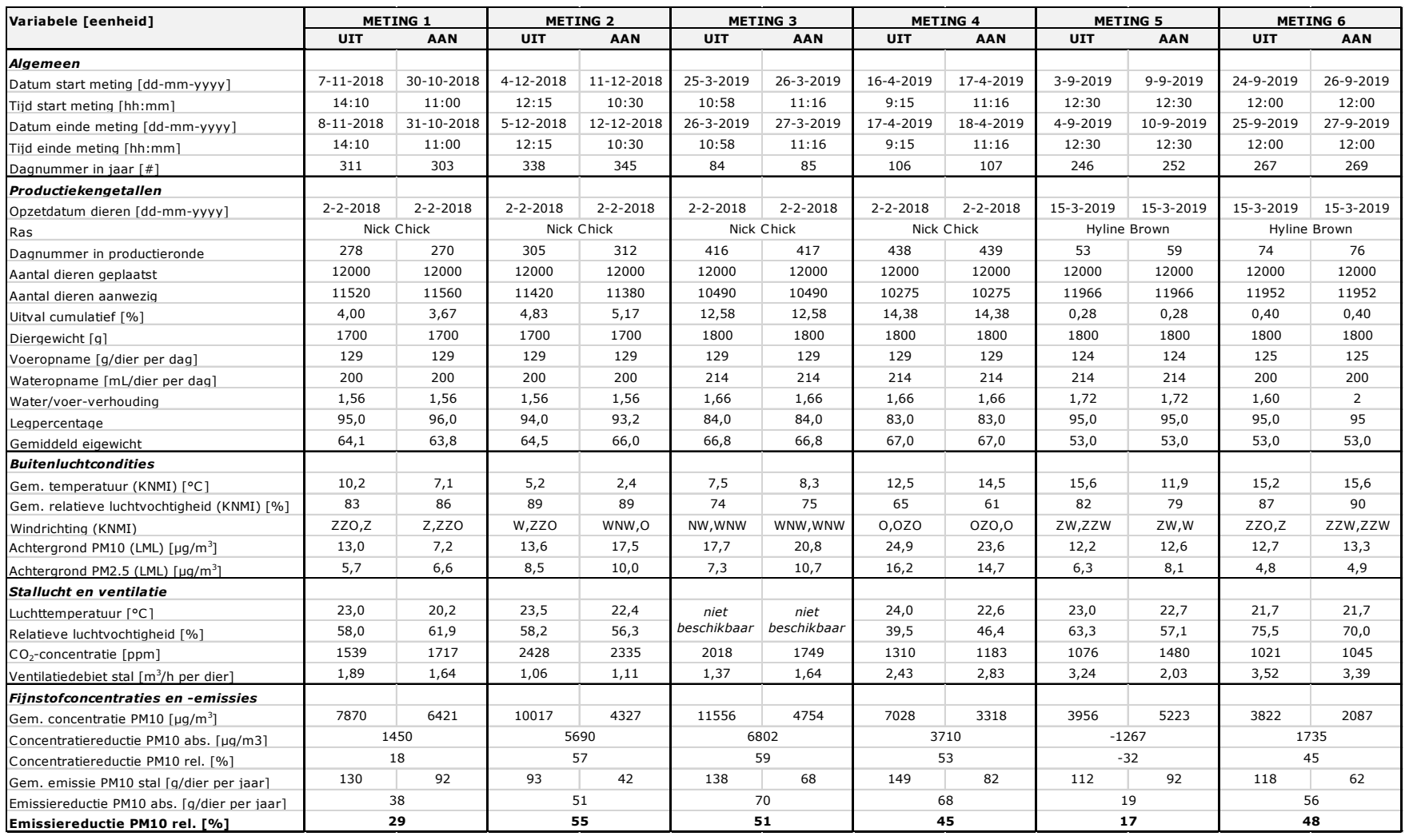




\section{2 $\mathrm{CO}_{2}$-concentratie en ventilatiedebiet}

Tabel 1 toont de gemeten $\mathrm{CO}_{2}$-concentraties. De gemiddelde $\mathrm{CO}_{2}$-concentratie in de stal bedroeg 1585 ppm voor de meetdagen met de techniek aan, versus 1565 ppm voor de meetdagen met de techniek uit. Uit de statistische analyse bleek dit verschil niet statistisch significant $(P=0,851)$. Op basis van o.a. de in tabel 1 weergegeven $\mathrm{CO}_{2}$-concentraties in de stal zijn de ventilatiedebieten berekend. In figuur 3.2 zijn deze weergegeven ten opzichte van het dagnummer in een kalenderjaar. Het ventilatiedebiet vertoont een normaal verloop over een kalenderjaar: stijgend in het voorjaar en dalend in het najaar. Dagen met debieten boven in de range (boven $4 \mathrm{~m}^{3} /$ uur per dier) ontbreken echter in de dataset. Een vergelijking met het verloop van het ventilatiedebiet met andere meetrapporten is moeilijk te maken, er zijn geen meetrapporten beschikbaar met metingen bij dezelfde dieren en huisvesting.

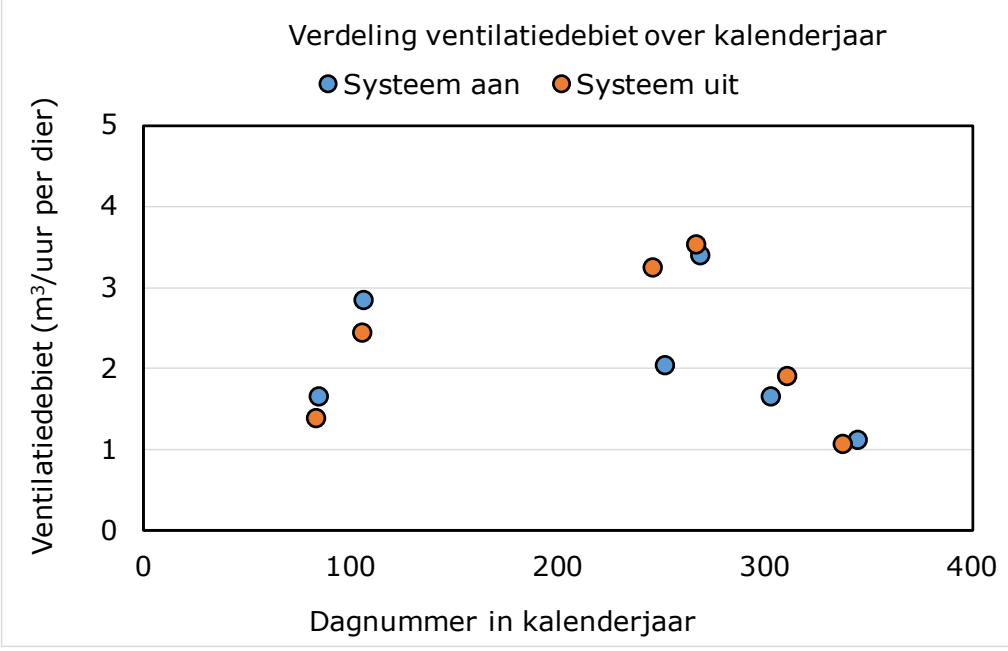

Figuur 3.2 Verdeling van het ventilatiedebiet over het kalenderjaar.

Het gemiddelde ventilatiedebiet ( \pm standaardafwijking) bedroeg $2,1( \pm 0,9) \mathrm{m}^{3} / \mathrm{uur}$ per dier voor meetdagen met de techniek aan versus $2,3( \pm 1,0) \mathrm{m}^{3} /$ uur per dier voor meetdagen met de techniek uit. Uit de statistische analyse bleek dit verschil niet statistisch significant $(P=0,561)$.

In figuur 3.3 is een nadere vergelijking uitgevoerd van het ventilatiedebiet tussen meetdagen met de techniek aan versus meetdagen met de techniek uit middels enkelvoudige lineaire regressieanalyse.

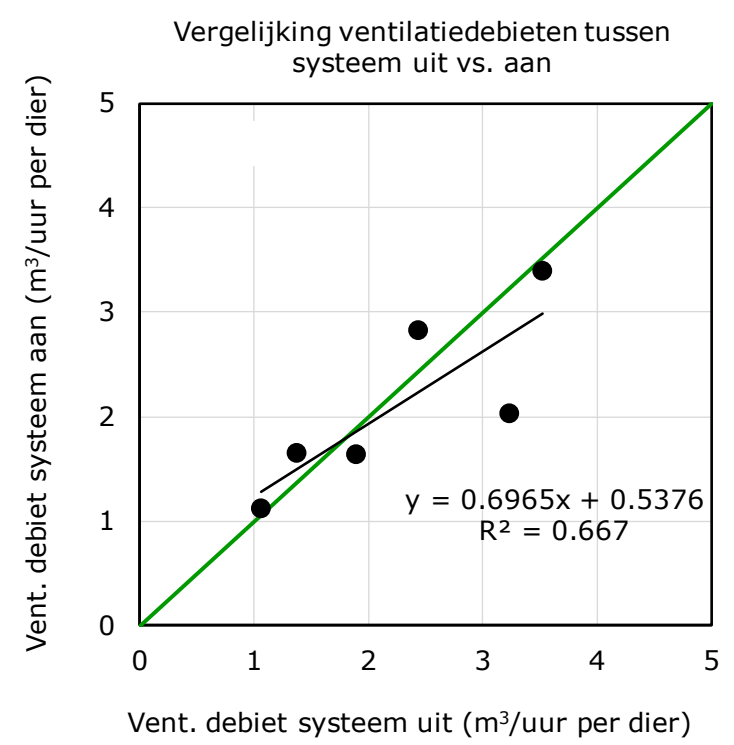

Figuur 3.3 Vergelijking van het ventilatiedebiet tussen meetdagen met de techniek aan versus meetdagen met de techniek uit. 
Uit de analyse blijkt dat de richtingscoëfficiënt van de regressielijn niet statistisch significant afwijkt van de waarde 1 (de groene $Y=x \operatorname{lijn} ; P=0,285$ ) en ook het snijpunt van de regressielijn is niet significant afwijkend van nul (d.w.z. door de oorsprong; $P=0,419$ ). Ook uit deze analyse blijkt dat de ventilatiedebieten zeer vergelijkbaar waren tussen dagen met het systeem aan en dagen met het systeem uit. Dit betekent dat er sprake is geweest van een zuivere vergelijkingsbasis in de meetstrategie v.w.b. het ventilatiedebiet.

\subsection{Concentratie, emissie en reductie $\mathrm{PM}_{10}$}

Voor het corrigeren van de emissie uit de stal met de achtergrondconcentratie, zijn de waarden gebruikt van het meetstation in Wekerom van het RIVM.

De concentraties en emissies van $\mathrm{PM}_{10}$ op meetdagen met de techniek aan en meetdagen met de techniek uit worden weergegeven in figuur 3.4. Uit de figuur blijkt dat de concentraties dalen en de emissies stijgen met toenemende temperaturen. De concentratie en emissie is waarschijnlijk afhankelijk van het ventilatiedebiet. In de figuur is te zien dat de emissies op de dagen met de techniek aan in alle gevallen lager was dan op de dagen met de techniek uit. Voor de concentraties is dit één keer niet het geval, waarschijnlijk door een groter verschil in ventilatiedebiet op deze meetdag.
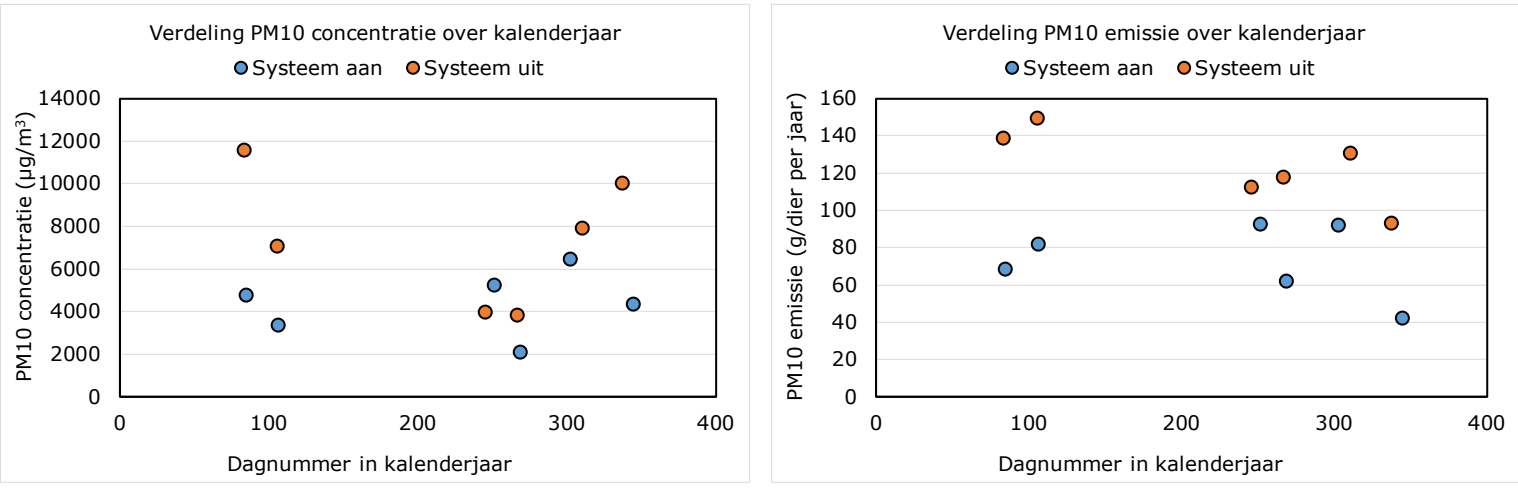

Figuur 3.4 PM10 concentraties (links) en PM10 emissies (rechts) op de meetdagen met de techniek aan en meetdagen met de techniek uit.

De gemiddelde ( \pm standaardafwijking) $\mathrm{PM}_{10}$ concentratie in de stal bedroeg $4355( \pm 1510) \mu \mathrm{g} / \mathrm{m}^{3}$ voor de meetdagen met de techniek aan versus $7375( \pm 3135) \mu \mathrm{g} / \mathrm{m}^{3}$ voor de meetdagen met de techniek uit. Uit de statistische analyse bleek dit verschil statistisch significant $(P=0,028)$.

De gemiddelde $\mathrm{PM}_{10}$ emissie uit de stal (berekend zoals beschreven in paragrafen 2.5.2 en 2.5.3) bedroeg 73,0 g/dier per jaar voor de meetdagen met de techniek aan versus 123,4 g/dier per jaar voor de meetdagen met de techniek uit. Uit de statistische analyse bleek het verschil in emissies statistisch significant $(P<0,001)$. Op basis van deze waarden bedraagt het eindreductiepercentage van de techniek $41 \%$. De emissieniveaus zijn representatief voor die normaliter in leghennenstallen optreden (Winkel et al., 2015b).

In figuur 3.5 worden de reductiepercentages weergegeven als functie van dagnummer in de productieronde, het ventilatiedebiet en de $\mathrm{PM}_{10}$ concentratie in de stal. Omdat het hier slechts gaat om zes waarnemingen van één locatie moet deze verkenning naar invloedsfactoren op de effectiviteit van de techniek met voorzichtigheid worden geïnterpreteerd. Het algemene beeld uit figuur 3.5 is die van een reductiepercentage welke niet wordt beïnvloed gedurende de productieperiode, door hogere stofconcentraties en het ventilatiedebiet. Van deze variabelen is het ventilatiedebiet niet statistisch significant van invloed op het reductiepercentage $(P=0,981)$, ook is er geen statistisch significante relatie gevonden met de $\mathrm{PM}_{10}$ concentratie $(P=0,244)$. Een afnemende effectiviteit van ionisatiesystemen in pluimveestallen tot het volgende schoonmaakmoment is bij dit systeem niet gevonden. Dit is in tegenstelling tot een negatief ionisatiesysteem van de firma Inter Continental (Ysselsteyn, Nederland), experimenteel onderzocht in een experimentele leghennenstal (Winkel et al., 2009) en in tegenstelling tot een positief ionisatiesysteem van de firma ENS Clean Air (Cuijk, Nederland) beproefd in twee leghennenstallen (Winkel et al., 2013). 
Verdeling PM10 emissiereductie over productieperiode

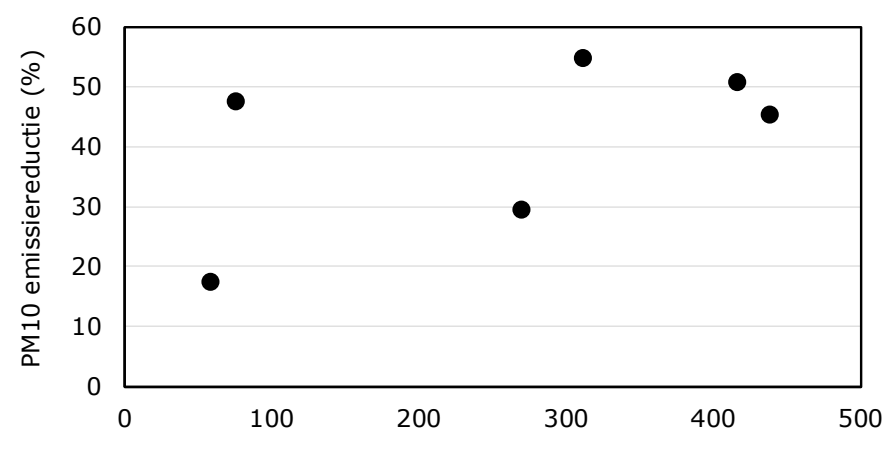

(a)

Dagnummer in productieronde (dag na opzet)

Relatie PM10 emissiereductie en ventilatiedebiet

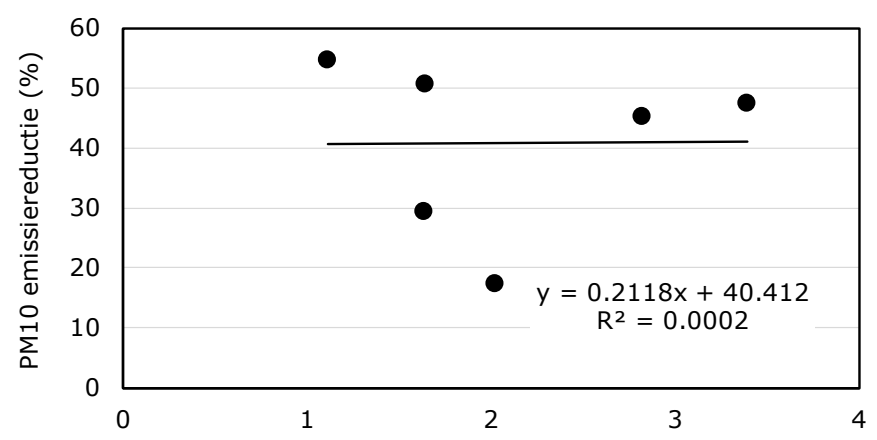

(b)

Ventilatiedebiet systeem aan $\left(\mathrm{m}^{3} / \mathrm{h}\right.$ per dier)

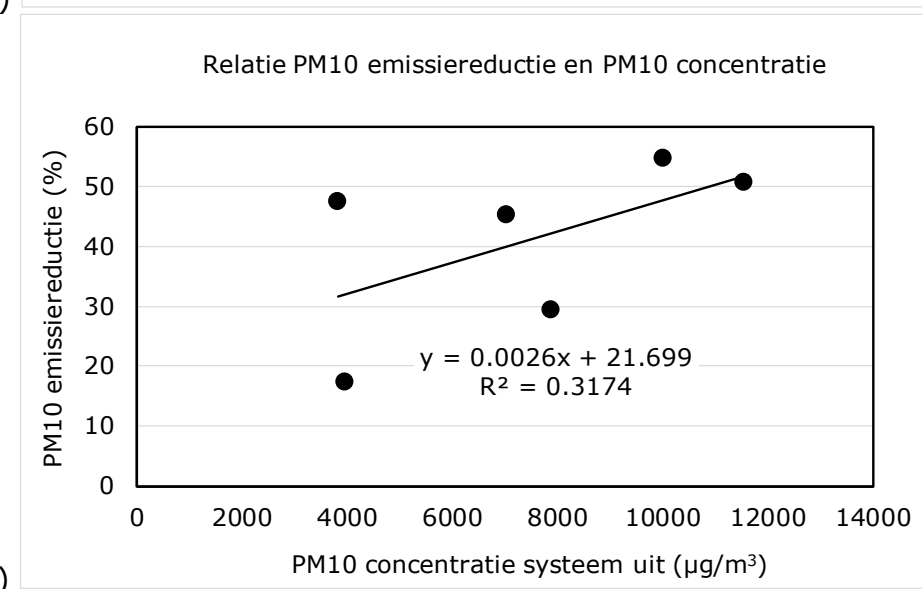

(c)

Figuur 3.5 Het reductiepercentage voor $P M_{10}$ als functie van (a) dagnummer in de productieronde, (b) het ventilatiedebiet en (c) de $P M_{10}$ concentratie in de stal. 


\section{$4 \quad$ Discussie}

Ten aanzien van de resultaten van de metingen en de vertaling ervan naar een reductiepercentage moeten de volgende discussiepunten in acht worden gehouden. De beoordeling van deze discussiepunten leiden uiteindelijk tot de conclusie verwoord in hoofdstuk 5.

Voor het toepassen van emissie reducerende technieken in stallen in het kader van het verkrijgen van een omgevingsvergunning dienen deze technieken opgenomen te zijn in de officiële "Lijst Emissiefactoren fijn stof voor veehouderij" zoals die regelmatig wordt geactualiseerd en gepubliceerd op de website van de Rijksoverheid (Rijksoverheid, 2018). Opname van de techniek in de lijst met een bepaald reductiepercentage vindt plaats nadat er door de leverancier van de techniek een aanvraag met een meetrapport is ingediend bij de Rijksdienst voor Ondernemend Nederland (RVO). Hoewel niet wettelijk vastgelegd (zoals dat overigens wel het geval is bij ammoniak) is het gebruikelijk dat het meetrapport en de daarin gevolgde methoden in overeenstemming zijn met het meetprotocol "Protocol voor meting van fijnstofemissie uit huisvestingssystemen in de veehouderij 2010" zoals gepubliceerd door Ogink et al. (2011). Om aanvragen te beoordelen vraagt RVO technisch advies aan de Technische Advies Pool (TAP). Dit is een pool van deskundigen die voor diverse bedrijven en organisaties werken. Het beoordelingsproces gaat via het beoordeling-review-principe. Dit betekent dat minimaal twee deskundigen de aanvraag beoordelen. Dit om tot een volwaardig eindadvies te komen. Op basis van dit eindadvies stelt de staatssecretaris van Infrastructuur en Waterstaat het uiteindelijk reductiepercentage vast.

Gezien de grote behoefte aan innovatieve technieken voor fijnstofreductie in de pluimveehouderij is in de fijnstofpilots in de Foodvalley regio beoogd om op een relatief goedkope en eenvoudige manier snel inzicht te krijgen in het perspectief en de reductie van zulke technieken. Daarom zijn er in de pilots een aantal bewuste omissies gepleegd t.a.v. de methodologie. Deze kunnen als volgt worden samengevat:

a. de gemiddelde emissiereductie is vastgesteld door een meetserie van zes metingen op één bedrijfslocatie i.p.v. twee meetseries van in totaal twaalf metingen op twee bedrijfslocaties zoals het meetprotocol dit voorschrijft;

b. Er is niet gemeten in een fysieke proefstal en een fysieke controlestal maar gemeten volgens een "case-control in de tijd" strategie. Een techniek wordt dan in een proefstal geïnstalleerd waarbij via metingen tijdens aan-dagen versus uit-dagen het reductiepercentage wordt bepaald

c. de concentraties en emissies van fijnstof $\left(\mathrm{PM}_{10}\right)$ zijn vastgesteld met DustTraks (een lichtverstrooiingsmethode) in plaats van met een gravimetrische meetmethode;

d. het ventilatiedebiet is vastgesteld aan de hand van de $\mathrm{CO}_{2}$-balansmethode op grond van metingen van $\mathrm{CO}_{2}$ in de stal (conform het meetprotocol), maar met een vaste (niet gemeten) achtergrondwaarde voor $\mathrm{CO}_{2}$ in de buitenlucht.

e. de achtergrondconcentraties van fijnstof $\left(\mathrm{PM}_{10}\right)$ zijn niet gemeten, hiervoor zijn achtergrondconcentraties gebruikt van het dichtstbijzijnde meetstation van het Luchtmeetnet (RIVM, 2019).

Voorafgaand aan de fijnstofpilots in de Foodvalley regio zijn deze omissies toegelicht en bediscussieerd met vertegenwoordigers van het Ministerie van IenW en RVO. Afgesproken is dat de meetrapporten uit de fijnstofpilots ingediend mogen worden bij RVO en zullen worden voorgelegd ter beoordeling en advisering door de TAP. Echter, daarbij is eveneens afgesproken dat in de discussie van het meetrapport een analyse en duiding zal plaatsvinden van de extra onzekerheid die de omissies in de fijnstofpilots met zich meebrengen. Op grond van die analyse en duiding, en op grond van de beoordeling en advisering door de TAP, kan er bij vaststelling van het reductiepercentage een onzekerheidsmarge worden afgetrokken van het verkregen resultaat uit een fijnstofpilot. Als een leverancier het reductiepercentage met onzekerheidsmarge wil vervangen door een definitief (d.w.z. betrouwbaarder en waarschijnlijk hoger) reductiepercentage, dan dient een meetrapport van een tweede meetserie op een tweede bedrijfslocatie te worden ingediend bij RVO. In de onderstaande tabel wordt voor een aantal betrouwbaarheidsintervallen de ondergrenzen van de reductiepercentages 
en de kans dat de reductie hoger is dan deze ondergrens weergegeven. Dit ten opzichte van het gemiddelde reductiepercentage van $41 \%$.

Tabel 2 Verschillende betrouwbarheidsintervallen met de kans dat het reductiepercentage hoger is dan de ondergrens en de ondergrens van het reductiepercentage.

\begin{tabular}{lrr} 
Betrouwbaarheidsinterval & $\begin{array}{c}\text { Ondergrens } \\
\text { reductiepercentage }\end{array}$ & $\begin{array}{c}\% \text { Kans dat reductie hoger is dan } \\
\text { ondergrens }\end{array}$ \\
\hline $95 \%$ & $25,7 \%$ & $\mathbf{9 7 , 5 \%}$ \\
\hline $90 \%$ & $29,0 \%$ & $\mathbf{9 5 \%}$ \\
\hline $80 \%$ & $32,1 \%$ & $\mathbf{9 0 \%}$ \\
\hline $70 \%$ & $34,0 \%$ & $\mathbf{8 5 \%}$ \\
\hline $60 \%$ & $35,4 \%$ & $\mathbf{8 0} \%$ \\
\hline $50 \%$ & $36,6 \%$ & $\mathbf{7 5 \%}$ \\
\hline
\end{tabular}

Hierna wordt ingegaan op de onzekerheid die omissies a, b, c, d en e met zich meebrengen.

\section{a. Eén i.p.v. twee bedrijfslocaties en zes in plaats van 12 metingen}

Volgens de gehanteerde meetprotocollen moet er bij een case-control meetstrategie gemeten worden op minimaal twee bedrijfslocaties om variatie in de prestatie van de techniek tussen verschillende stallen mee te nemen in het eindreductiepercentage. In dit rapport zijn de resultaten weergegeven van metingen op één bedrijfslocatie. Op deze locatie kan de techniek - om welke reden dan ook systematisch beter of slechter hebben gepresteerd dan de werkelijke gemiddelde prestatie zoals die theoretisch verkregen zou kunnen worden door de techniek te bemeten op een zeer groot aantal locaties. Enig inzicht in de tussenbedrijfsvariatie van ionisatietechnieken kan verkregen worden uit de meetrapporten van een negatief ionisatiesysteem van de firma Inter Continental (Ysselsteyn, Nederland) beproefd op twee vleeskuikenbedrijven en een positief ionisatiesysteem van de firma ENS Clean Air (Cuijk, Nederland) beproefd in twee leghennenstallen (beide meetrapporten zijn gepubliceerd als wetenschappelijk artikel met hierin individuele reductiepercentages per locatie door Winkel et al., (2016)). T.a.v. de eerste ionisatietechniek bedroeg het gemiddelde $\mathrm{PM}_{10}$ reductiepercentage $47 \%$ met reductiepercentages per bedrijfslocatie van gemiddeld $46 \%$ voor bedrijf 1 en $49 \%$ voor bedrijf 2 . T.a.v. de tweede ionisatietechniek bedroeg het gemiddelde $\mathrm{PM}_{10}$ reductiepercentage $6 \%$ met reductiepercentages per bedrijfslocatie van gemiddeld $12 \%$ voor bedrijf 1 en $4 \%$ voor bedrijf 2 . Deze twee ionisatietechnieken laten dus een vergelijkbaar beeld (kleine tussenbedrijfsvariatie) zien in beide bedrijfslocaties. Voor voornoemde twee technieken geldt dat op de kleinst mogelijke schaal ( 2 bedrijfslocaties) is laten zien dat het reductiepercentage reproduceerbaar is. Dit kan voor de techniek in dit rapport vergelijkbaar gelden, maar wellicht ook niet. Daarover wordt pas meer inzicht/betrouwbaarheid verkregen door een meetserie bij een tweede bedrijfslocatie uit te voeren.

De keuze in de fijnstofpilots om metingen uit te voeren op één bedrijfslocatie brengt verder met zich mee dat het reductiepercentage van $41 \%$ gebaseerd is op één meetserie van zes in plaats van 12 waarnemingen. De gevonden reductie is statistisch significant afwijkend van nul. Het 95\%betrouwbaarheidsinterval (de bovengrens en ondergrens waartussen voornoemde eindreductiepercentage met $95 \%$ zekerheid ligt) bedraagt de gevonden reductie \pm 15 procentpunten. Als echter een volledige dataset van 12 waarnemingen op twee locaties voorhanden zou zijn, en als de spreiding in die dataset gelijk zou blijven aan die in de huidige dataset, dan zou t.g.v. het grotere aantal waarnemingen het $95 \%$-betrouwbaarheidsinterval dalen tot \pm 11 procentpunten.

Voor het vaststellen van een onzekerheidsmarge kan ook gebruik worden gemaakt van andere meetseries uit het verleden. In Winkel (2020) is dit gedaan voor de reductiepercentages voor PM10 van de al in de regelgeving opgenomen technieken. Op basis van die analyse wordt een onzekerheidsmarge voorgesteld van 10 procentpunten ten opzichte van het gemeten bedrijfsgemiddelde. Daarmee is het advies voor deze techniek om een voorlopig reductiepercentage van $31 \%$ op te nemen in de landelijke regelgeving. 


\section{b. Case-control in de tijd strategie i.p.v. fysieke proef- en controlestallen}

Vaak is het moeilijk om twee echt identieke praktijkstallen te vinden, zo ook in deze pilot. Daarom is er gemeten volgens een "case-control in de tijd" strategie. Een techniek wordt dan in een proefstal geïnstalleerd waarbij via metingen tijdens aan-dagen versus uit-dagen het reductiepercentage wordt bepaald. Zowel de case-control als de case-control in de tijd strategie kennen hun voordelen en aandachtspunten. Bij twee identieke stallen worden in de praktijk toch vaak kleine (systematische) verschillen gezien in binnenklimaat en luchtkwaliteit, bijvoorbeeld doordat de ene stal overwegend in de luwte van de andere staat of er kleine verschillen bestaan in de klimaatregeling. Ook bij identieke stallen bestaan er soms verschillen in dierprestaties (bijvoorbeeld in uitval) en verschilt de natheid van het strooisel t.g.v. de vertering door de dieren. Zulke kleine verschillen kunnen worden geneutraliseerd door de behandeling telkens te wisselen tussen stallen. Dit is echter met technische systemen die moeten worden ingebouwd een kostbare, tijdrovende en onpraktische werkwijze. In een case-control in de tijd strategie bestaan voornoemde onzuiverheden tussen stallen niet. De stal waar de proefbehandeling wordt toegepast is kort daarvoor, of kort daarna, ook de stal waar de controlemeting wordt verricht. Bij deze strategie zijn er twee aandachtspunten: de aan-meting en de uit-meting dienen zo dicht mogelijk bij elkaar te worden uitgevoerd om te grote verschillen in met name ventilatiedebiet te voorkomen en de aan- en uit-perioden mogen elkaar niet beïnvloeden. Indien aan deze voorwaarden wordt voldaan is de case-control in de tijd strategie een voldoende zuivere vergelijkingsbasis. De case-control in de tijd strategie is in de laatste versies van de Nederlandse meetprotocollen nog niet opgenomen, de strategie komt wel voor in het VERA-protocol voor "Livestock housing and management systems" (VERA, 2018b). De strategie is verder bij metingen aan reductietechnieken voor fijnstof de afgelopen jaren veel toegepast. Resultaten verkregen met deze strategie zijn geaccepteerd in peer-reviewed wetenschappelijke tijdschriften en door de rijksoverheid geaccepteerd voor opname in de officiële "Lijst Emissiefactoren fijn stof voor veehouderij". Hier behoeven de Nederlandse protocollen een update.

\section{c. Meetmethode $P M_{10}$ indirect equivalent aan EN 12341:2014}

De toegepast meetmethode voor $\mathrm{PM}_{10}$ (DustTraks, modellen 8520 en 8530) kent twee soorten fouten: de methode onderschat de werkelijke $\mathrm{PM}_{10}$ concentratie in stallen (systematische fout of bias) en de methode kent een relatief grote variatie tussen apparaten (toevalsfout). Om deze reden was de methode nog niet opgenomen in het meetprotocol voor fijnstof (Ogink et al., 2011).

Echter, in het meest recente VERA protocol (VERA, 2018a) wordt reeds de eis gesteld dat een $\mathrm{PM}_{10}$ meetmethode equivalent dient te zijn aan de EN 12341:2014 referentiesampler (CEN, 2014). Door correctiefactoren te gebruiken op de ruwe data van de DustTrak is dit apparaat indirect equivalent aan de referentiesampler gemaakt. De relatief grote toevalsfout van de methode is gecompenseerd door de metingen in duplo, d.w.z. met twee apparaten, uit te voeren. Wanneer beide DustTraks goed hebben gemeten is het gemiddelde van beide concentraties genomen. Als bij een meting één DustTrak niet goed gemeten heeft, wordt deze data niet gebruikt. Dit is het geval geweest bij meting 6 . Als beide apparaten niet goed gemeten hebben is de gehele meting niet gebruikt. Daarnaast zijn de diverse apparaten in de pilot voorafgaand aan en na afloop van elke meting met elkaar vergeleken om afwijkende apparaten op te sporen en vroegtijdig te reinigen en onderhouden. Op deze wijze zijn de DustTrak modellen inzetbaar voor het bemeten van relatieve verschillen tussen case- en controledagen. Hier behoeft het Nederlandse protocol uit 2011 een update. Voor het meten van PM 10 emissiefactoren die dus op absolute schaal accuraat dienen te zijn, verdient een gravimetrische methode de voorkeur. Deze methode is direct equivalent aan EN 12341:2014 en kent een kleinere toevalsfout tussen apparaten.

\section{d. Gevoeligheidsanalyse voor geen plaatselijke meting van $\mathrm{CO}_{2}$-achtergrondconcentraties}

$\mathrm{Er}$ is bij deze metingen voor gekozen om geen concentraties van $\mathrm{CO}_{2}$ in de directe nabijheid van de stal te meten. In plaats daarvan is voor $\mathrm{CO}_{2}$ gekozen voor een vaste waarde van 400 ppm die in werkelijkheid tot enkele tientallen ppm's hoger of lager zou kunnen zijn geweest. Om het effect van een lagere of hogere $\mathrm{CO}_{2}$-achtergrond inzichtelijk te maken is het reductiepercentage nogmaals doorgerekend op basis van een zeer lage vaste achtergrond van 300 ppm én een zeer hoge vaste achtergrond van 500 ppm (deze achtergrondconcentraties werken door in de berekening van het ventilatiedebiet middels de $\mathrm{CO}_{2}$-balansmethode en vervolgens in de emissieberekeningen en het reductiepercentage). De aldus verkregen reductiepercentages bedroegen 40,6\% bij 300 ppm, 40,9\% 
bij 400 ppm en 41,3\% bij 500 ppm. Uit deze gevoeligheidsanalyse blijkt dat het reductiepercentage nauwelijks wordt beïnvloed door de gekozen vaste achtergrond voor $\mathrm{CO}_{2}$. Dit komt doordat a) het concentratieverschil tussen binnen en buiten groot is, en b) de kleine "fout" bij het berekenen van het ventilatiedebiet op zowel case- als controledagen wordt gemaakt. Bij lagere concentratieverschillen tussen binnen en buiten, en bij het bemeten van een absolute emissiefactor, dient overigens altijd een $\mathrm{CO}_{2}$-achtergrond te worden bepaald.

e. Gevoeligheidsanalyse voor geen plaatselijke meting van PM10-achtergrondconcentraties $\mathrm{Er}$ is bij deze metingen voor gekozen om geen concentraties van $\mathrm{PM}_{10}$ in de directe nabijheid van de stal te meten. In plaats daarvan is voor $\mathrm{PM}_{10}$ de gemiddelde concentratie tijdens de meetdagen van het dichtstbijzijnde meetstation van het RIVM gebruikt. Om het effect van een lagere of hogere $\mathrm{PM}_{10}$ achtergrond inzichtelijk te maken is het reductiepercentage nogmaals doorgerekend op basis van een verlaging of verhoging van de $\mathrm{PM}_{10}$-achtergrondconcentratie met $20 \mu \mathrm{g} / \mathrm{m}^{3}$ (deze achtergrondconcentraties werken door in de emissieberekeningen en het reductiepercentage). De aldus verkregen reductiepercentages bedroegen $41,0 \%$ bij een verlaging met $20 \mu \mathrm{g} / \mathrm{m}^{3}, 40,9 \%$ bij de achtergrondconcentratie van het dichtstbijzijnde meetstation en 40,7\% bij een verhoging met 20 $\mu \mathrm{g} / \mathrm{m}^{3}$. Uit deze gevoeligheidsanalyse blijkt dat het reductiepercentage nauwelijks wordt beïnvloed door de $\mathrm{PM}_{10}$-achtergrondconcentratie. Dit komt doordat a) het concentratieverschil tussen binnen en buiten groot is, b) de kleine "fout" bij het berekenen van de emissie op zowel case- als controledagen wordt gemaakt, en c) de windrichting op beide meetdagen per aan-uit meting vergelijkbaar is geweest. Bij lagere concentratieverschillen tussen binnen en buiten, en bij het bemeten van een absolute emissiefactor, dient overigens altijd een $\mathrm{PM}_{10}$-achtergrond te worden bepaald.

Hierna wordt nog ingegaan op een aantal algemene discussiepunten.

\section{Verdeling metingen over jaar en productieperiode}

Uit paragraaf 3.1 blijkt dat de metingen niet helemaal evenwichtig verdeeld zijn over alle fasen van het kalenderjaar. Dit is enerzijds inherent aan een meetserie van zes geslaagde metingen. Anderzijds had de pilot te maken met incidenten in de sector, leegstand van een bedrijf door het afleveren en weer opzetten van dieren en het uitvallen van meettechnici door ziekte. Omdat de metingen niet zijn gericht op het vaststellen van een absolute emissiefactor maar op een reductiepercentage, en omdat het werkingsprincipe van ionisatietechnieken waarschijnlijk niet wordt beïnvloed door seizoensinvloeden, is de onzekerheid die deze omissie veroorzaakt waarschijnlijk klein.

\section{Landbouwkundige voorwaarden}

De metingen voldoen grotendeels aan de landbouwkundige voorwaarden beschreven in bijlage 2 . Een punt waar niet aan voldaan wordt is het hogere uitvalspercentage. Dit percentage is in de eerste productieronde hoger geweest dan de norm in de landbouwkundige voorwaarden. Dit kan verklaard worden doordat het uitvalspercentage in de biologische sector gemiddeld hoger is dan in de reguliere sector (KWIN-V 2019-2020). Ook kunnen andere factoren hebben meegespeeld, dit heeft echter niet of nauwelijks effect op het emissie reducerende principe van deze techniek.

\section{Stabilisatietijd}

Tijdens één meting is de stabilisatietijd van minimaal één uur niet in acht genomen, de data laten geen reden zien deze meting te laten vervallen.

\section{Andere meetrapporten}

Er zijn bij deze techniek geen andere metingen uitgevoerd conform meetprotocollen voor de agrarische sector (Ogink et al., 2011). Wel zijn door de leverancier in eigen beheer metingen uitgevoerd. Deze metingen zijn niet conform meetprotocol uitgevoerd en met niet gevalideerde meetapparatuur. Eén meting is op dezelfde locatie uitgevoerd als de locatie in dit rapport. Over een kort tijdsbestek zijn reducties gevonden van 50 tot $63 \%$ op de fijnstofconcentratie in de stal (Monteny Milieu Advies, 2019). Deze reducties liggen hoger dan de in dit rapport vermelde reductiepercentages. 


\section{PM2.5}

In dit onderzoek zijn geen metingen verricht naar de reductie van $\mathrm{PM}_{2.5}$. Op basis van de studie van Cambra-López et al. (2009) is het te verwachten dat ook dit systeem een lagere reductie zal geven voor $\mathrm{PM}_{2.5}$.

\section{Ozon}

Ionisatie kan leiden tot de productie van ozon. In de studie van Cambra-López et al. (2009) is de ozonconcentratie altijd onder de minimale detectiewaarde gebleven. Alleen bij hele lage ventilatiedebieten zoals bij jonge vleeskuikens kon een bepaalde ozongeur waargenomen worden. Zodra de ventilatie minimaal begon te draaien waren er geen aanwijzingen meer voor de aanwezigheid van ozon.

\section{Methaan/lachgas}

Voor zover bekend heeft ionisatie geen effect op het ontstaan of verwijderen van methaan $\left(\mathrm{CH}_{4}\right)$ en lachgas $\left(\mathrm{N}_{2} \mathrm{O}\right)$ uit stallucht. Hieraan zijn in dit project ook geen metingen verricht.

\section{Brandgevaar}

Onderzoek uitgevoerd naar het brandgevaar van een andere ionisatietechniek gaf aan dat de kans op een stofexplosie door ontladingen van het ionisatiesysteem verwaarloosbaar klein is (de Feijter en Reijman, 2014). Er zijn geen redenen voor een hoger gevaar bij het ionisatiesysteem beschreven in dit rapport.

\section{Elektromagnetische velden}

De hoge spanning toegepast bij ionisatie zorgt voor een elektromagnetisch veld, wat mogelijk zorgt voor gezondheidseffecten bij mens en dier. In dit rapport is geen verder onderzoek gedaan naar het optreden hiervan bij dit ionisatiesysteem. Aangenomen mag worden dat leverancier het systeem dusdanig uitvoert dat dit geen schadelijke effecten tot gevolg zal hebben.

\section{Vertaling naar andere pluimveecategorieën}

De HD-ionisatielampen zijn binnen de pluimveehouderij in ieder geval toepasbaar bij leghennen, zowel regulier als biologisch. Daarnaast zou het systeem toegepast kunnen worden bij andere diercategorieën binnen de hoofdcategorie Kippen (E) en Kalkoenen (F), omdat de HD-ionisatielampen niet onderhevig lijken te zijn aan effecten van ventilatiedebiet, fijnstofconcentratie in de stal of productiestadium. Het onderhavige meetrapport biedt daarover echter geen duidelijkheid. De strooiselkwaliteit van vleeseenden verschilt van die van andere pluimveecategorieën in met name het drogestofgehalte (ca. 30\% t.o.v. >50\%). Tevens wordt in de tweede helft van de groeiperiode, na overplaatsing van de dieren naar een andere stal, dagelijks nieuw strooisel aangebracht. Toepassing van het systeem tijdens de eerste fase van de groeiperiode, voor overplaatsen, zou daarmee mogelijk zijn. Of tijdens de tweede fase van de groeiperiode eenzelfde effect wordt bereikt zal met metingen moeten worden onderzocht. 


\section{$5 \quad$ Conclusie en advies}

De HD-ionisatielampen van de firma Freshlight zijn in staat de emissie van $\mathrm{PM}_{10}$ in leghennenstallen te reduceren. Op grond van zes metingen aan één leghennenstal, waarbij de relevante meetprotocollen zoveel mogelijk zijn gevolgd, bedraagt deze reductie gemiddeld $41 \%$. Deze reductie is statistisch significant verschillend van nul. Rekening houdend met een onzekerheidsmarge van 10 procentpunten vanwege het meten op slechts één bedrijfslocatie, is het advies om een reductiepercentage op te nemen van $31 \%$. 


\section{Literatuur}

Aarnink, A.J.A., Cambra-López, M., Lai, H.T.L., Ogink, N.W.M. 2011. Deeltjesgrootteverdeling en bronnen van stof in stallen. Rapport 452. Lelystad: Wageningen UR Livestock Research.

Cambra-López, M., Winkel, A., Van Harn, J., Ogink, N. W. M., \& Aarnink, A. J. A. (2009). Ionization for reducing particulate matter emissions from poultry houses. Transactions of the ASABE, 52(5), 1757-1771.

Cambra-Lopez, M. ; Winkel, A. ; Mosquera Losada, J. ; Ogink, N.W.M. ; Aarnink, A.J.A. 2015. Comparison between light scattering and gravimetric samplers for PM10 mass concentration in poultry and pig houses. Atmos. Environ. 111:20-27. Lelystad: Wageningen UR Livestock Research.

CEN. 2014. Ambient air - Standard gravimetric measurement method for the determination of the PM10 or PM2,5 mass concentration of suspended particulate matter. Brussel, Belgie: European Committee for Standardization (CEN).

CIGR. 2002. 4th Report of Working Group on Climatization of animal houses. Heat and moisture production at animal and house levels (eds. Pedersen, S. and K. Sällvik). International Commission of Agricultural Engineering (CIGR), Section II.

Feijter de, M. P., \& Reijman, P. B. (2014). Brandveiligheid stofafvangsystemen in kippenstallen. Efectis Nederland.

Freshlight. 2019. Over Ionisatie. Online beschikbaar op: https://www.freshlight.eu/nl/over/overionisatie

Gezondheidsraad. 2018. Gezondheidswinst door schonere lucht. Den Haag: Gezondheidsraad.

Hagenaars, T., Hoeksma, P., de Roda-Husman, A.M., Swart, A., Wouters, I. 2017. Veehouderij en Gezondheid Omwonenden (aanvullende studies). Analyse van gezondheidseffecten, risicofactoren en uitstoot van bioaerosolen. Rapport 2017-0062. Bilthoven: RIVM.

Heederik D.J.J. \& IJzermans, C.J.. 2011. Mogelijke effecten van intensieve-veehouderij op de gezondheid van omwonenden: onderzoek naar potentiële blootstelling en gezondheidsproblemen. Utrecht: IRAS-UU. Utrecht: NIVEL. Bilthoven: RIVM.

Heederik, D., Erbrink, H., Farokhi, A., Hagenaars, T., Hoek, G., Ogink, N., de Rooij, M., Smit, L., Winkel, A., Wouters, I. Risicomodellering veehouderij en gezondheid (RVG): modellering van regionale endotoxineconcentraties en relaties met gezondheidseffecten. Rapport IRAS UU 2019-01 / WBVR-1910304. Utrecht: Institute for Risk Assessment Sciences. Lelystad: Wageningen Bioveterinary Research.

Hendriks, C., Kranenburg, R., Kuenen, J., van Gijlswijk, R., Wichink Kruit, R., Segers, A., Denier van der Gon, H., Schaap, M. 2013. The origin of ambient particulate matter concentrations in the Netherlands. Atmos. Environ. 69:289-303.

IJzermans, C.J., Smit, L.A.M., Heederik, D.J.J., Hagenaars, T.J. 2018. Veehouderij en gezondheid omwonenden III: longontsteking in de nabijheid van geiten- en pluimveehouderijen; actualisering van gegevens uit huisartspraktijken 2014-2016. Utrecht: NIVEL.

KWIN 2018-2019 Handboek 41, Kwantitatieve informatie Veehouderij 2018-2019. September 2019.

Maassen, K., Smit, L., Wouters, I., van Duijkeren, E., Janse, I., Hagenaars, T., IJzermans, J., van der Hoek, W., Heederik, D. 2016. Rapport 2016-0058. Bilthoven, Nederland: RIVM.

Monteny Milieu Advies. 2019. Monitoring emissiereductie door ioniserende verlichting.

Ogink, N. W. M., P. Hofschreuder, A. J. A. Aarnink. 2011. Protocol voor meting van fijnstofemissie uit huisvestingssystemen in de veehouderij 2010. Rapport 492. Lelystad: Wageningen University and Research Centre, Livestock Research.

Ogink, N.W.M., Mosquera, J., Hol, J.M.G., 2017. Protocol voor meting van ammoniakemissie uit huisvestingssystemen in de veehouderij 2013a. Wageningen Livestock Research, Rapport 1032.

Pedersen, S., Blanes-Vidal, V., Joergensen, H., Chwalibog, A., Haeussermann, A., Heetkamp, M.J.W., Aarnink, A.J.A. 2008. Carbon dioxide production in animal houses: a literature review. Agricultural Engineering International: CIGR Ejournal, Vol. X, December 2008. Manuscript BC 08008.

Rijksoverheid. 2018. Emissiefactoren fijn stof voor veehouderij. Excelfile online gepubliceerd 15-032018. Online beschikbaar op: 
https://www.rijksoverheid.nl/documenten/publicaties/2018/03/15/emissiefactoren-fijn-stof-voorveehouderij-2018.

Rijksoverheid. 2019. Bijlage 1, bedoeld in artikel 2, eerste lid, van de Regeling ammoniak en veehouderij. Versie 26 april 2019. Online beschikbaar op: https://wetten.overheid.nl/BWBR0013629/2019-04-26\#Bijlage1.

RIVM. 2019. Stations. Online beschikbaar op: https://www.luchtmeetnet.nl/stations/alleprovincies/alle-gemeentes/alle-stoffen

VERA. 2018a. Vera test protocol for air cleaning technologies. Version 2:2018-09. Delft, the Netherlands: International VERA Secretariat.

VERA. 2018b. Vera test protocol for livestock housing and management systems. Version 3:2018-09. Delft, the Netherlands: International VERA Secretariat.

VSN. 2018. GenStat reference manual (release 19). Hemel Hempstead, UK: VSN International Ltd.

WHO. 2015. WHO Air quality guidelines for particulate matter, ozone, nitrogen dioxide and sulfur dioxide - Global update 2005. Geneva, Switzerland: World Health Organization.

Winkel, A., Emous, R.A. van, Kwikkel, R.K., Ogink, N.W.M., Aarnink, A.J.A. 2009. Maatregelen ter vermindering van fijnstofemissie uit de pluimveehouderij: ionisatie bij leghennen in volièrehuisvesting. Rapport 203. Lelystad: Animal Sciences Group, Wageningen UR.

Winkel, A., Nijeboer, G.M., Huis in 'T Veld, J.W.H., Ogink, N.W.M. 2013. Maatregelen ter vermindering van fijnstofemissie uit de pluimveehouderij: validatie van een ionisatiesysteem op leghennenbedrijven. Rapport 685. Lelystad: Wageningen UR Livestock Research.

Winkel, A., Wouters, I.M., Aarnink, A.J.A., Heederik, D.J.J., Ogink, N.W.M. 2014. Emissies van endotoxinen uit de veehouderij: een literatuurstudie voor ontwikkeling van een toetsingskader. Rapport 773. Wageningen: Wageningen Livestock Research.

Winkel, A., Llorens Rubio, J., Huis in 't Veld, J.W.H., Vonk, J.A., Ogink, N.W.M. 2015a. Equivalence testing of filter-based, beta-attenuation, TEOM, and light-scattering devices for measurement of $\mathrm{PM}_{10}$ concentration in animal houses. J. Aeros. Sci. 80:11-26.

Winkel, A., Mosquera Losada, J., Groot Koerkamp, P.W.G., Ogink, N.W.M., Aarnink, A.J.A. 2015b Emissions of particulate matter from animal houses in the Netherlands. Atmos. Environ. 111:202212.

Winkel, A. 2016. Particulate matter emission from livestock houses: measurement methods, emission levels and abatement systems. PhD Thesis. Wageningen, the Netherlands: Wageningen University \& Research.

Winkel, A., Mosquera Losada, J., Aarnink, A.J.A., Groot Koerkamp, P.W.G., Ogink, N.W.M. 2016. Evaluation of oil spraying systems and air ionisation systems for abatement of particulate matter emission in commercial poultry houses. Biosyst. Eng. 150:104-122.

Winkel, A. 2020. Berekening van een onzekerheidsmarge voor fijnstof reducerende technieken bemeten bij één in plaats van twee bedrijfslocaties. Wageningen Livestock Research, Report 1239. 


\section{Bijlage 1 Beschrijving stal}

\begin{tabular}{|c|c|}
\hline Kenmerk & Beschrijving \\
\hline \multicolumn{2}{|l|}{ Stal } \\
\hline Bouwjaar & 1994 \\
\hline Rav code en omschrijving & $\begin{array}{l}\text { E } 2.11 .4 \text { volièrehuisvesting, } 55-60 \% \text { van de leefruimte } \\
\text { roosters met daaronder een mestband met } 0,7 \mathrm{~m}^{3} \text { per dier } \\
\text { per uur mestbeluchting. Mestbanden minimaal eenmaal } \\
\text { per week afdraaien. Roosters minimaal in twee etages } \\
\text { (BWL } 2005.05 . V 1) \text {. Biologische leghennen met uitloop }\end{array}$ \\
\hline \multirow[t]{3}{*}{ Emissiefactoren } & Emissie $\mathrm{PM}_{10}: 65 \mathrm{~g} /$ dierplaats per jaar \\
\hline & Emissie ammoniak: 0,037 kg/dierplaats per jaar \\
\hline & Emissie geur: 0,34 OU $\mathrm{E}_{\mathrm{E}}$ dierplaats per seconde \\
\hline Afmetingen $\left(\mathrm{I} \times \mathrm{b} \times \mathrm{h}_{\text {goot }} / \mathrm{h}_{\text {nok }}\right)$ & $90 \times 9,5 \times 2,8 \times 4,25 \mathrm{~m}$ \\
\hline Oriëntatie van de stal & OON (voorgevel) - WWZ (achtergevel) \\
\hline \multicolumn{2}{|l|}{ Dieren } \\
\hline Aantal hennen bij opzet & Ca. 12.000 \\
\hline Bezettingsgraad bij opzet & Ca. 14 kippen per $\mathrm{m}^{2}$ strooiselvloeroppervlak \\
\hline Merk hen & Nick Chick (wit) later Hyline Brown (bruin) \\
\hline \multicolumn{2}{|l|}{ Klimaatregeling } \\
\hline Beschrijving luchtinlaat & $\begin{array}{l}\text { Via inlaat-ventielen in de zijgevels en via mestband- } \\
\text { beluchting: } 0,7 \mathrm{~m}^{3} / \text { uur per hen }\end{array}$ \\
\hline \multirow[t]{3}{*}{ Beschrijving luchtuitlaat } & Stal met 4 compartimenten (niet luchtdicht gescheiden). \\
\hline & \\
\hline & Totaal: ca. $52.000 \mathrm{~m}^{3} / \mathrm{uur}$ (ca. $5 \mathrm{~m}^{3} / \mathrm{uur}$ per hen) \\
\hline Ventilatieregeling & Op basis van staltemperatuur en onderdruk \\
\hline Streeftemperatuur & Ca. $19-20^{\circ} \mathrm{C}$ \\
\hline Verwarmingssysteem & Geen \\
\hline \multicolumn{2}{|l|}{ Bedrijfsvoering } \\
\hline Beschrijving houderijsysteem & $\begin{array}{l}\text { Volièrehuisvesting in } 2 \text { systeemrijen en } 3 \text { strooiselgangen. } \\
\text { Het systeem is } 37 \text { secties van elk } 2,30 \text { m lang } \\
\text { (systeemlengte: ca. } 85,10 \mathrm{~m} \text { ) }\end{array}$ \\
\hline Beschrijving voersysteem & $\begin{array}{l}\text { Voerkettingen door het volièresysteem: twee circuits per } \\
\text { systeemrij }\end{array}$ \\
\hline Voertijden & $\begin{array}{l}\text { Voertijden: vijf- tot zesmaal per dag, verspreid over de } \\
\text { lichtperiode }\end{array}$ \\
\hline Voer & Legmeel 1,2 en 3 \\
\hline Beschrijving drinkwatersysteem & $\begin{array}{l}\text { Waterlijnen met drinknippels en lekschoteltjes: drie lijnen } \\
\text { per systeemrij }\end{array}$ \\
\hline Drinktijden & Tijdens lichttijden \\
\hline Strooiselmanagement & $\begin{array}{l}\text { De stal wordt ingestrooid met een kleine hoeveelheid stro. } \\
\text { Verder wordt incidenteel strooisel uitgereden }\end{array}$ \\
\hline Beschrijving verlichting & $\begin{array}{l}\text { Lichtstraten boven de strooiselgangen met full spectrum } \\
\text { LED-lampen }\end{array}$ \\
\hline Lichtregime & 16L:8D, licht aan van 04:00-20:00 uur (wintertijd) \\
\hline Schoonmaakregime & $\begin{array}{l}\text { Na ruimen van de kippen wordt de strooiselmest } \\
\text { verwijderd en de stal nat gereinigd }\end{array}$ \\
\hline \multicolumn{2}{|l|}{ Productiecyclus } \\
\hline Leeftijd bij opzet & Ca. 17 weken \\
\hline Leeftijd bij ruimen & Ca. 80 weken \\
\hline Leegstand tussen koppels & Ca. 2 weken \\
\hline
\end{tabular}




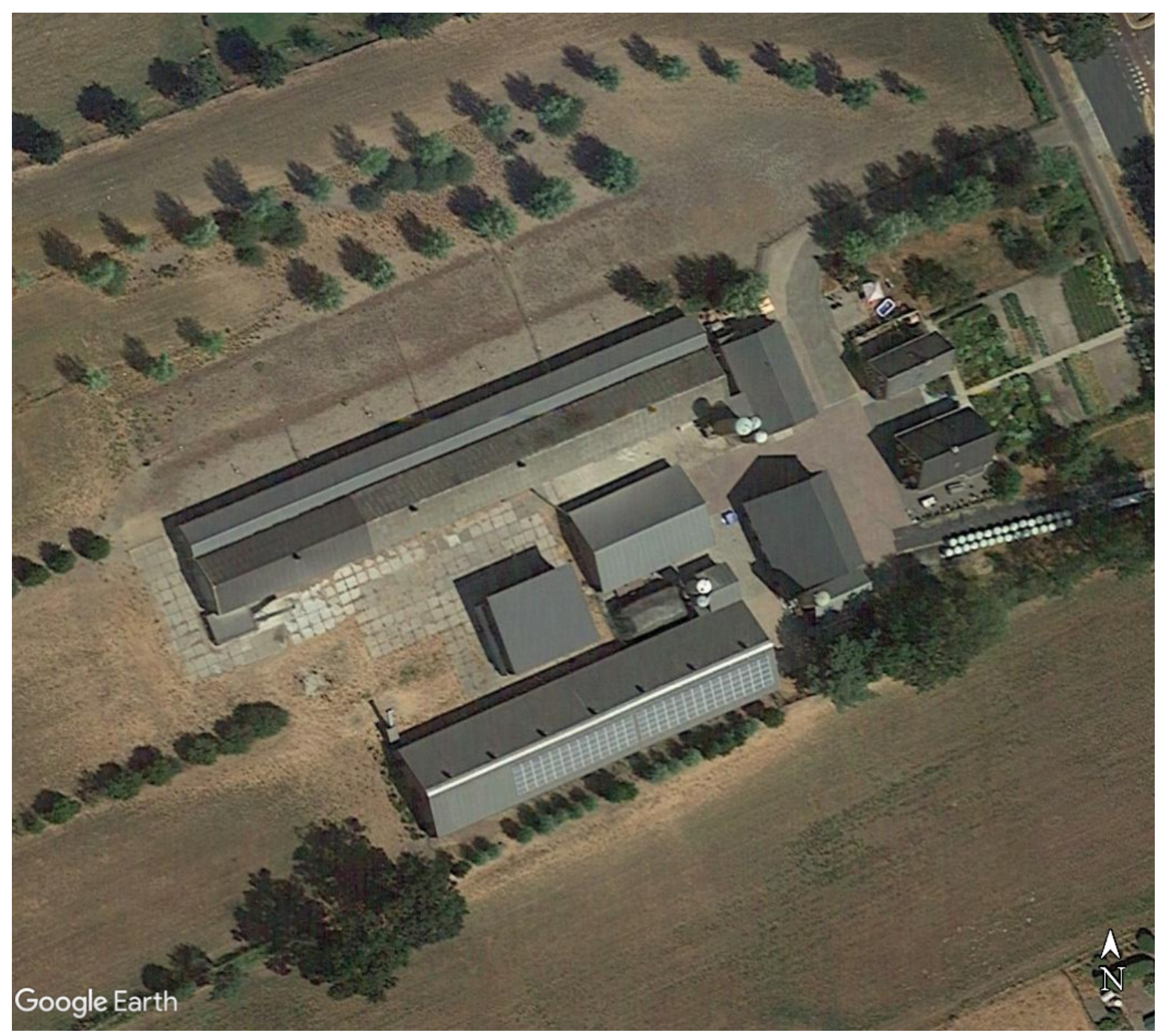

Luchtfoto bedrijf. De pluimveestal waar is gemeten is de bovenste stal.

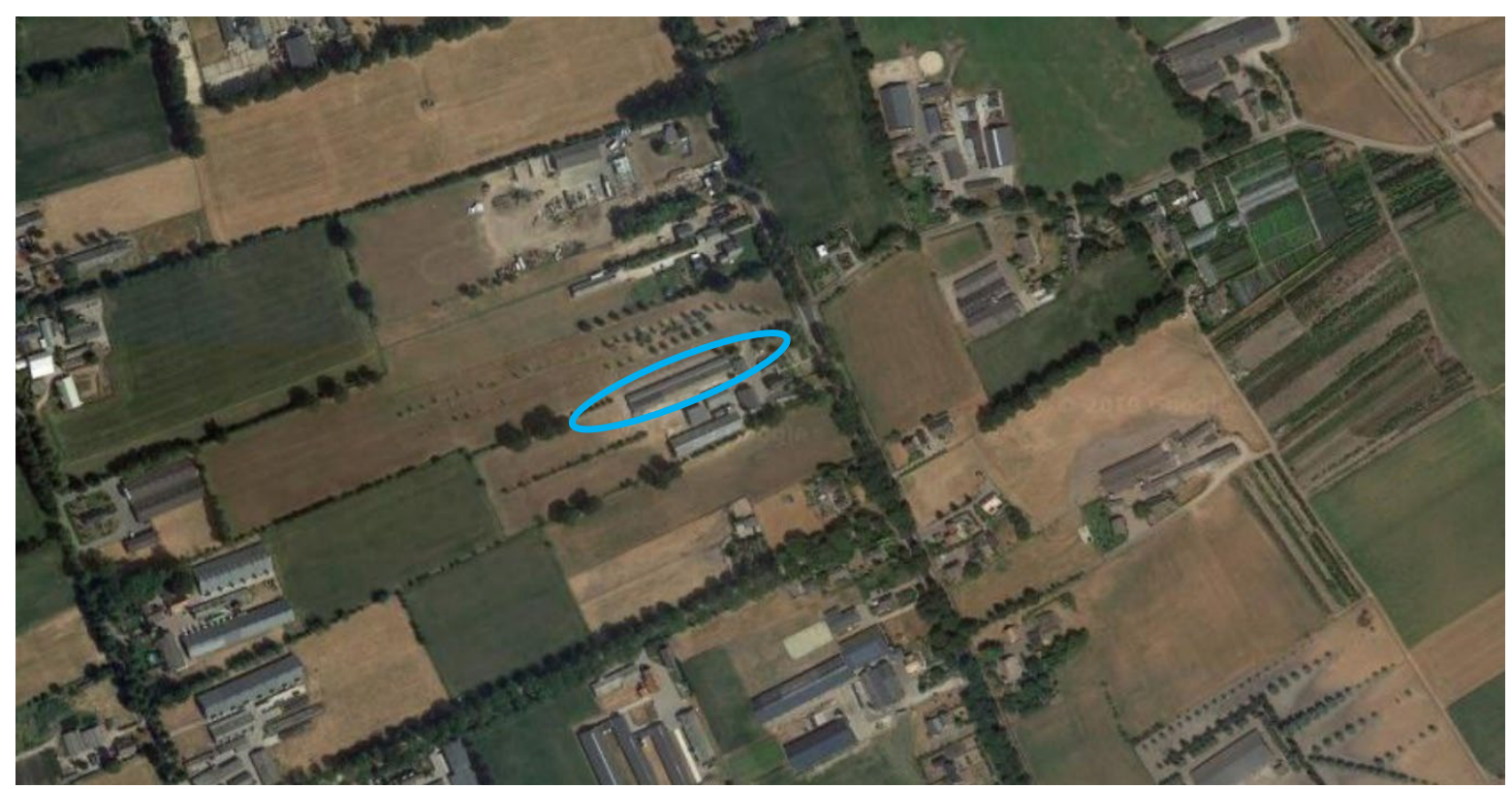

Luchtfoto bedrijf met omgeving. De pluimveestal waar is gemeten is de blauw omcirkeld. 


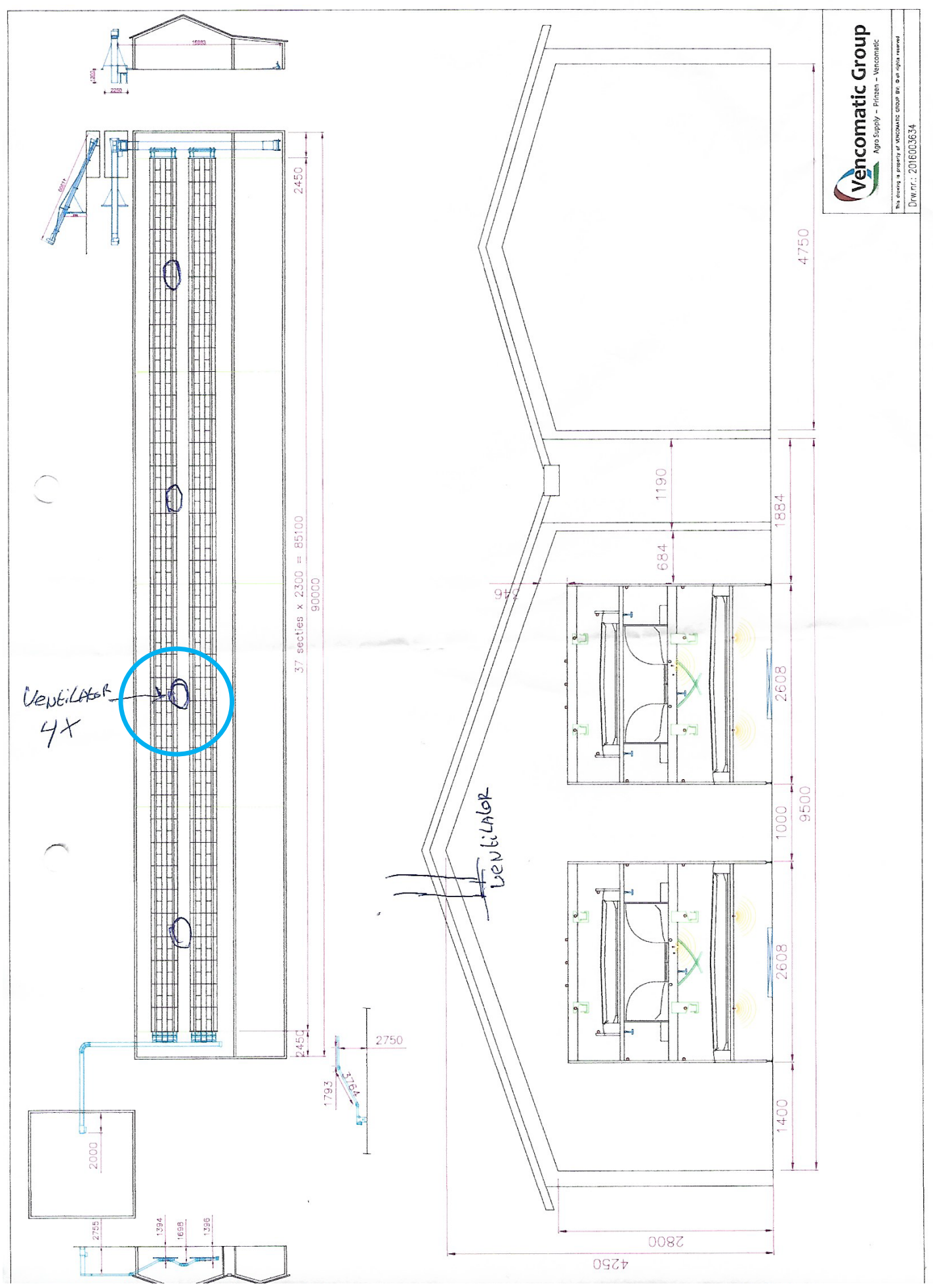

Plattegrond en doorsnede stal. Metingen zijn uitgevoerd bij de blauw omcirkelde ventilatiekoker. 


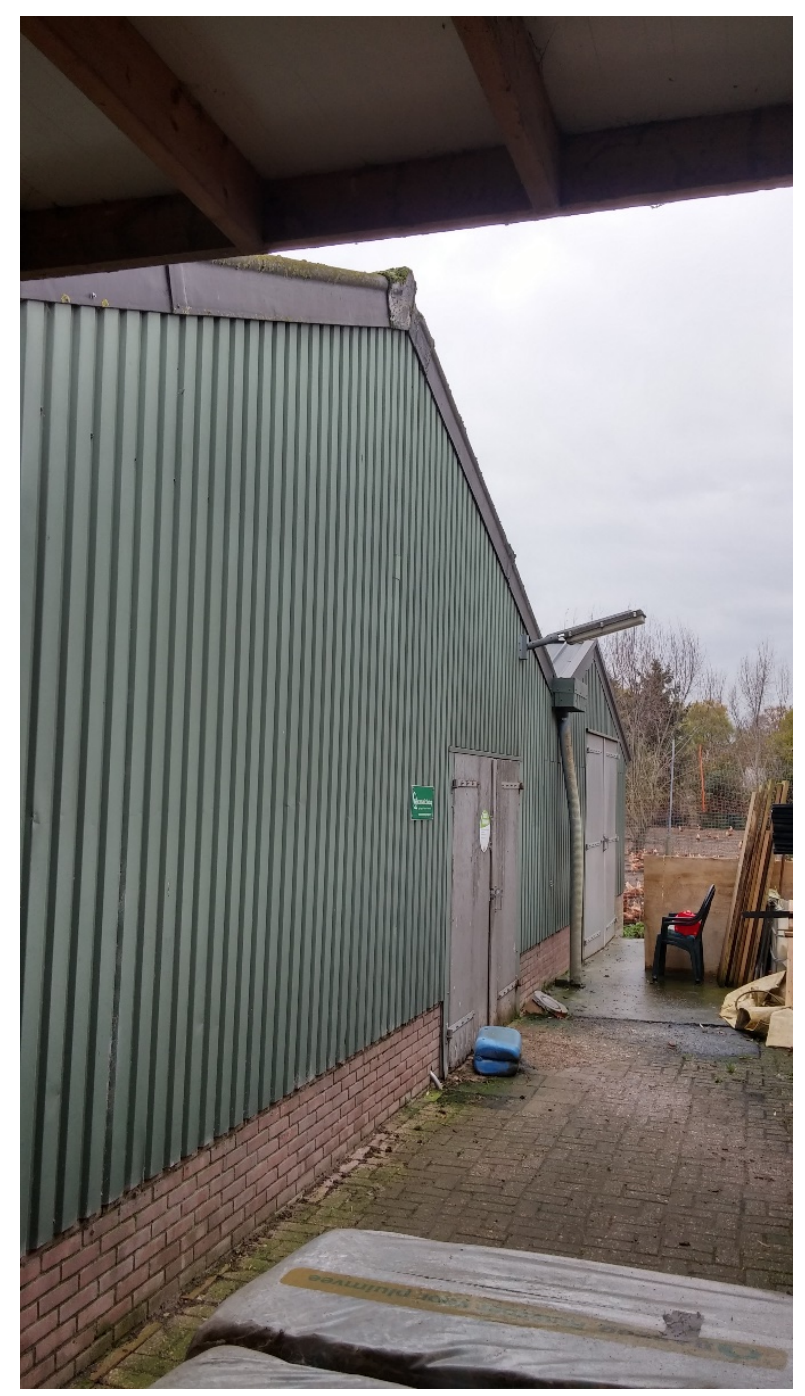

Vooraanzicht stal

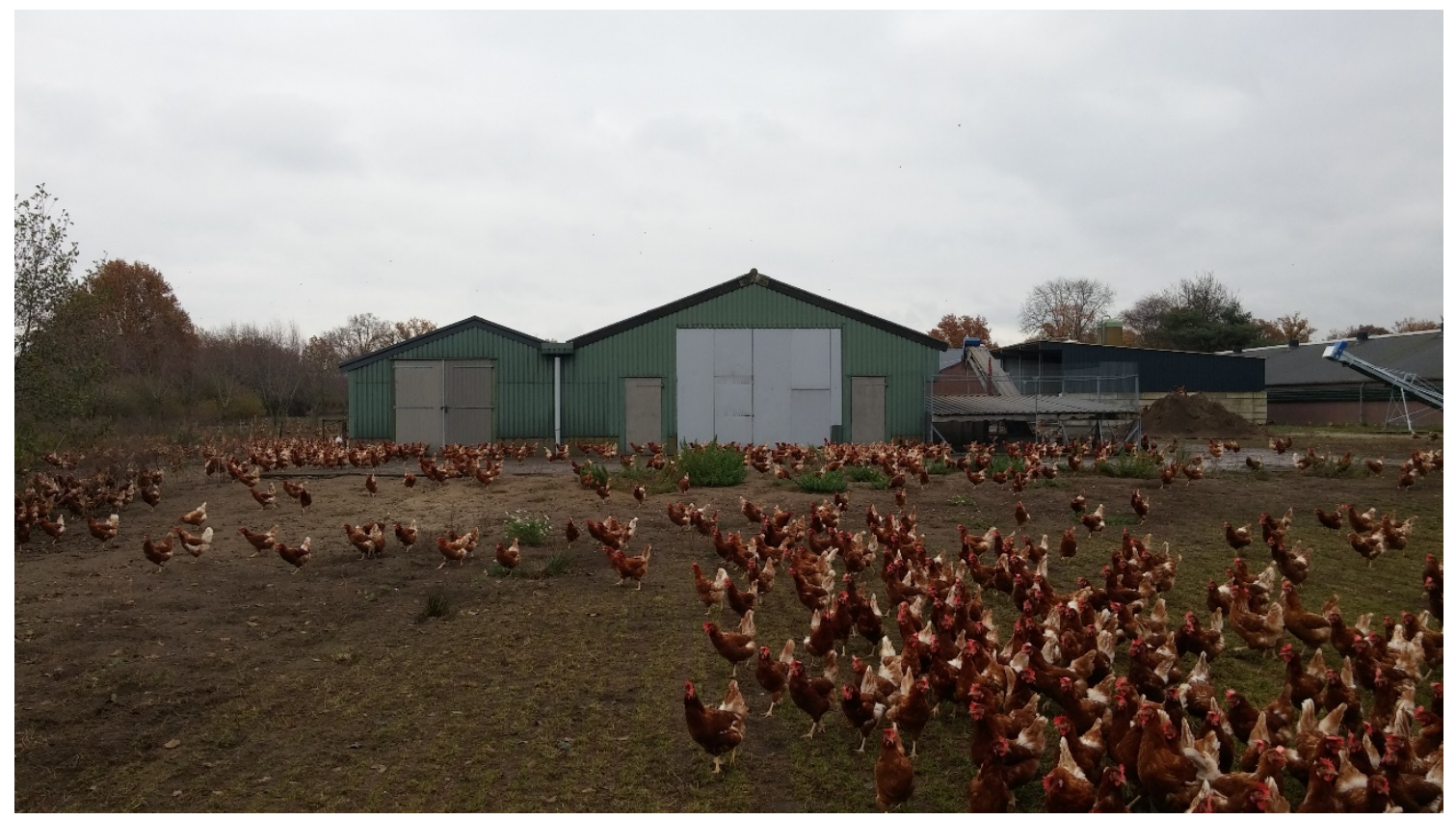

Achteraanzicht stal 


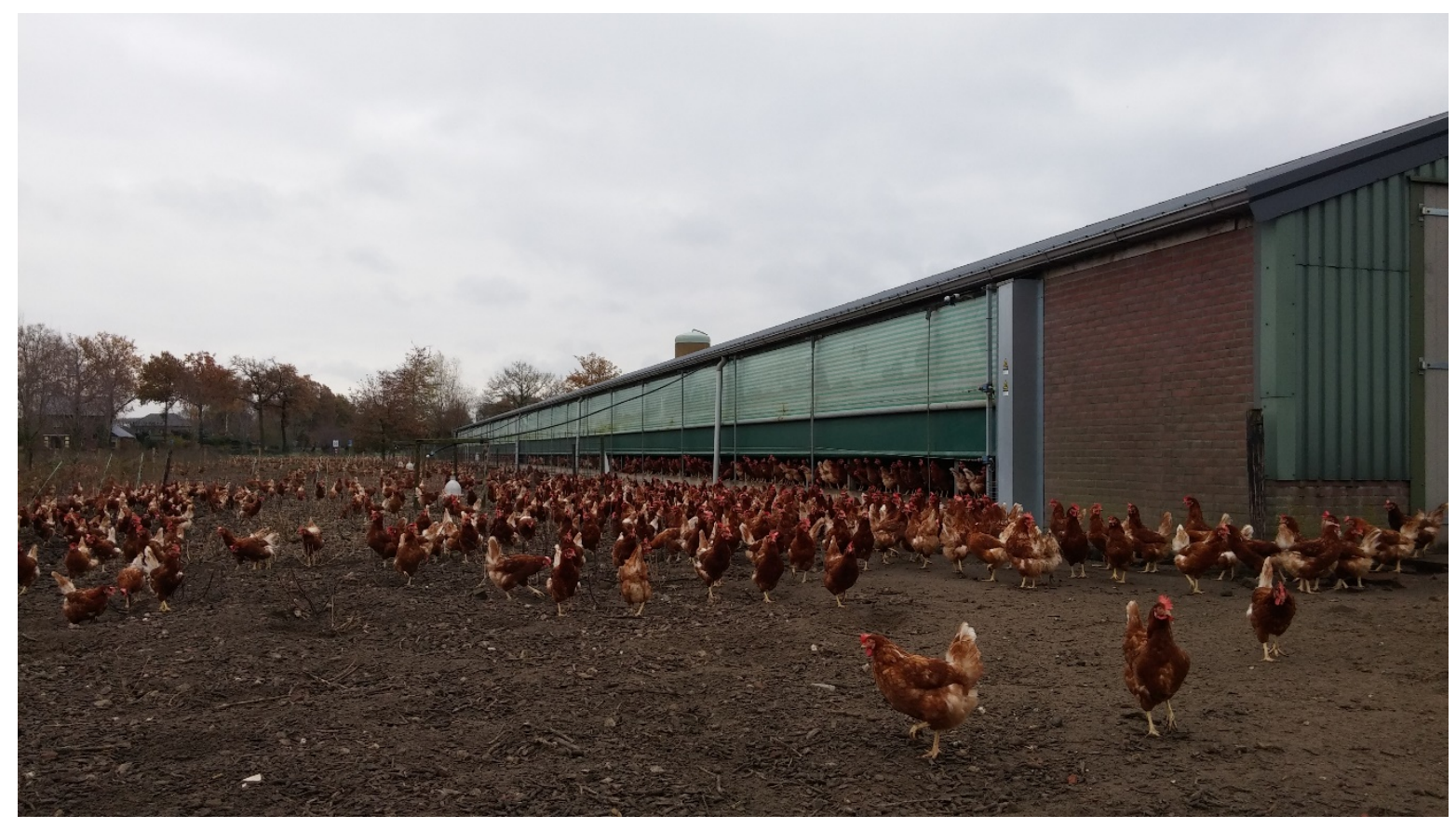

Zijaanzicht stal met overdekte uitloop (niet in gebruik tijdens metingen)
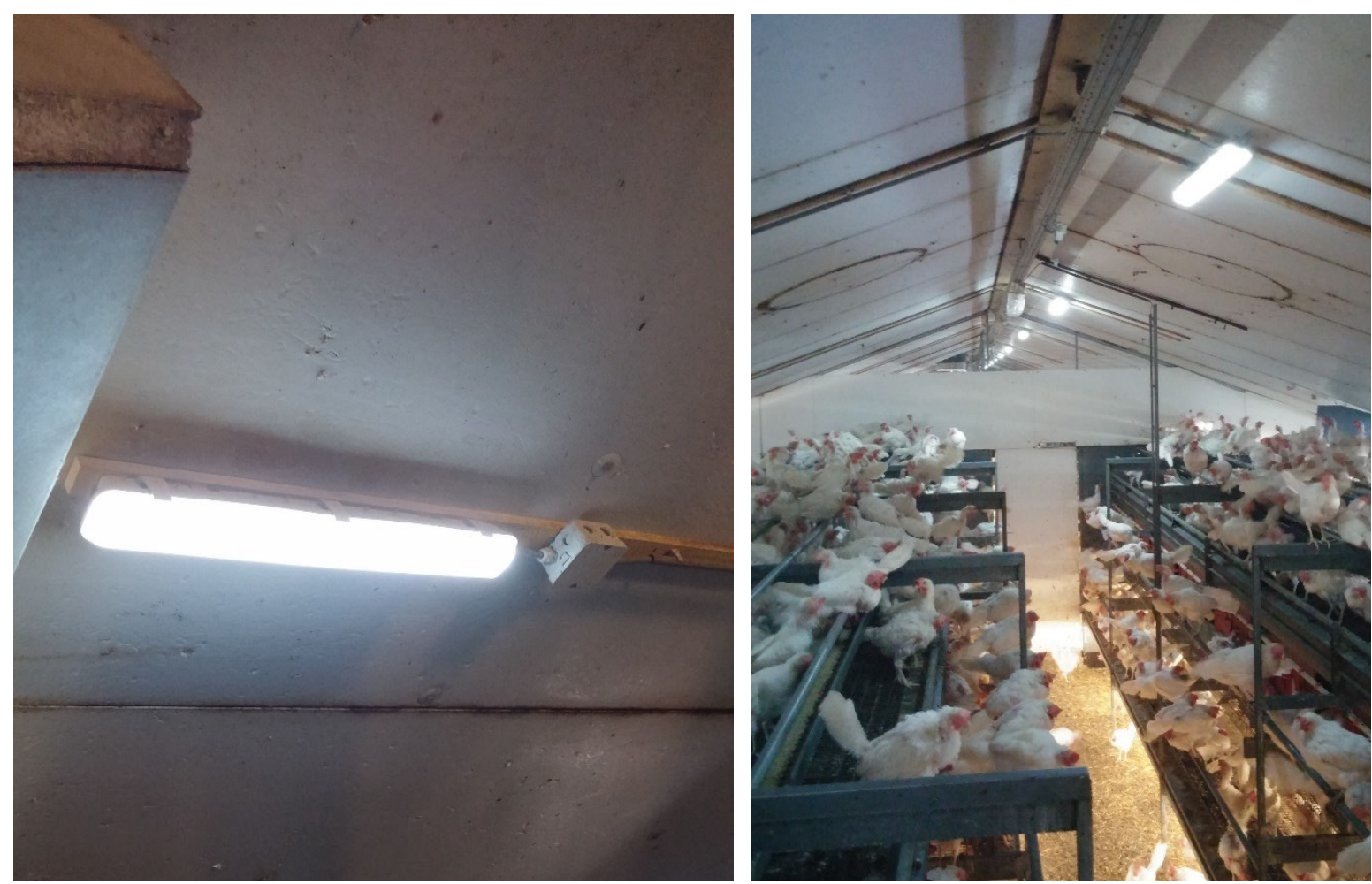

HD-ionisatielampen op twee plekken in de stal 


\section{Bijlage 2 Landbouwkundige voorwaarden}

\begin{tabular}{|c|c|c|}
\hline Onderdeel & Landbouwkundige voorwaarde: & Voldoet \\
\hline Huisvesting & $\begin{array}{l}\text { Tijdens de meetperiode wordt voldaan aan de geldende } \\
\text { dierwelzijnsnormen. } \\
\text { Vóór de meetperiode moet de stal minstens twee maanden gebruikt zijn } \\
\text { voor de huisvesting van legkippen. }\end{array}$ & $\begin{array}{l}\mathrm{Ja} \\
\mathrm{Ja}\end{array}$ \\
\hline Klimaat & $\begin{array}{l}\text { De legkippen worden gehouden onder zodanige omstandigheden dat de } \\
\text { CO2-concentratie in de lucht van de afdeling onder de } 3.000 \text { ppm blijft. }\end{array}$ & $\mathrm{Ja}$ \\
\hline Voeding & $\begin{array}{l}\text { De kippen krijgen een gangbaar voerschema (CVB) met minimaal } 14 \mathrm{~g} \\
\text { RE/omzetbare energie leghennen (OEIh in MJ/kg) in het voer. Het } \\
\text { voerverbruik per aanwezige legkip vanaf } 20 \text { weken dient minimaal } 105 \\
\text { g per dier per dag te zijn. Waterverstrekking gebeurt onbeperkt. } \\
\text { Verklaring van geen gebruik van diervoedertoevoegingsmiddelen die } \\
\text { mogelijk als hoofd- of nevenwerking een verlagend effect hebben op de } \\
\text { pH van de urine en/of de ureumuitscheiding via de urine. }\end{array}$ & $\begin{array}{l}\text { Ja, deze gehalten } \\
\text { hebben geen effect op } \\
\text { fijnstofemissie } \\
\text { Ja, deze gehalten } \\
\text { hebben geen effect op } \\
\text { fijnstofemissie }\end{array}$ \\
\hline Productie & De eiproductie moet op jaarbasis minimaal 300 eieren/kip zijn. & $\mathrm{Ja}$ \\
\hline $\begin{array}{l}\text { Gezondheid } \\
\text { en hygiëne }\end{array}$ & $\begin{array}{l}\text { De legkippen krijgen standaard veterinaire zorg. Het uitvalspercentage } \\
\text { mag niet hoger zijn dan } 10 \% \text { in de volledige productieperiode. }\end{array}$ & $\begin{array}{c}\text { Nee, metingen zijn } \\
\text { uitgevoerd in stal met } \\
\text { biologische leghennen } \\
\text { die een hoger } \\
\text { uitvalspercentage } \\
\text { hebben, zie KWIN-V }\end{array}$ \\
\hline $\begin{array}{l}\text { Aantal } \\
\text { dieren }\end{array}$ & De groepsgrootte bedraagt minimaal 750 & $\mathrm{Ja}$ \\
\hline Registratie & \begin{tabular}{|l|} 
- totaal aantal kg verstrekt voer in de afdeling/stal \\
- totaal aantal kg verstrekt strooisel in de afdeling/stal \\
- totale hoeveelheid waterverbruik in de meetafdeling/stal \\
- aanwezige + ingaande en uitgaande dieren (ook tijdens de meting) \\
Tijdens de meting: \\
- productie: aantal eieren, eigewicht en uitval \\
- voeropname \\
- tijdstippen van verwijderen van (drijf)mest uit de afdeling/stal \\
- registratie van voersamenstelling \\
- co2-concentratie \\
- de wijze waarop voldaan wordt aan tijdens de meetperiode \\
geldende dierwelzijnsnormen
\end{tabular} & $\begin{array}{c}\text { Nee, deze kengetallen } \\
\text { hebben nauwelijks } \\
\text { effect op de reductie } \\
\text { van fijnstof }\end{array}$ \\
\hline
\end{tabular}




\section{Bijlage 3 Bepaling correctiefactor voor DustTrak model 8530}

De relatie tussen de $\mathrm{PM}_{10}$ concentratie bepaald met de DustTrak en de gravimetrische methode voor PM10 zoals die in gebruik is bij Wageningen Livestock Research is bepaald door in twee verschillende leghennenstallen simultane metingen $(n=8)$ uit te voeren met beide methoden naast elkaar. Van de twee methoden is de gravimetrische methode equivalent aan de $\mathrm{PM}_{10}$ referentiesampler in EN 12341:2014 (CEN, 2014).

In onderstaande figuren zijn de relaties tussen beide meetmethoden weergegeven. In de linker figuur is de equivalente methode op de $\mathrm{x}$-as geplaatst en de DustTrak model 8530 op de $\mathrm{Y}$-as. Uit de linker figuur blijkt dat de puntenwolk en de bijbehorende regressielijn onder de groene $Y=x$ lijn ligt. Dit betekent dat de DustTrak de werkelijke concentratie onderschat.

In de rechter figuur is vervolgens de DustTrak model 8530 op de $x$-as geplaatst en de equivalente methode op de $Y$-as. In de bijbehorende regressiefunctie $Y=2,5263 x$ is nu $x$ de DustTrak concentratie. Wil men de DustTrak concentratie $x$ omrekenen naar de werkelijke concentratie $Y$, dan moet die concentratie $x$ vermenigvuldigd worden met de factor 2,5263 of afgerond $\mathbf{2 , 5 3}$.
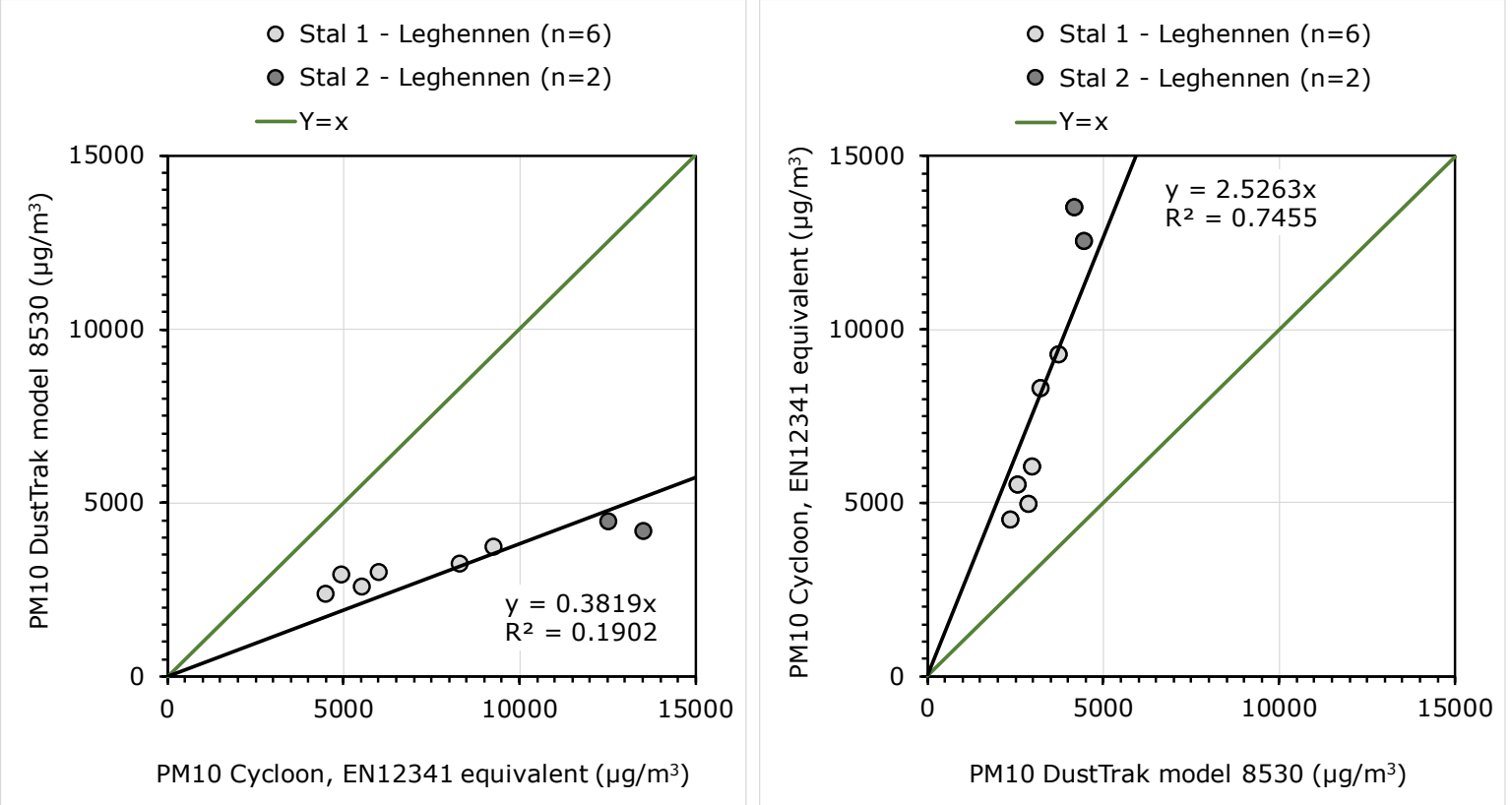


\section{Bijlage 4 Kalibratie meetapparatuur}

Fijnstof-analyse $P M_{10}$ DustTrak Aerosol Monitor Model 8520 en DustTrak II Aerosol Monitor Model 8530.

Alle gebruikte instrumenten hebben een recent certificaat van de leverancier. Na iedere stalmeting van ruim 2 × 24 uur zijn de instrumenten van buiten en binnen goed schoon gemaakt en indien nodig weer van een nieuw filter voorzien. Dit laatste geeft het instrument zelf aan.

Vervolgens hebben de instrumenten in het luchtlaboratorium gedurende enkele dagen in de zogenaamde survey-mode gedraaid. Hierbij wordt het instrument gespoeld met de relatief schone omgevingslucht. Middels een 'nul-filter' is gecontroleerd of de zero-waarde moest worden aangepast. Bij model 8520 werd voor iedere meting de nieuwe nul-waarde ingevoerd. Bij model 8530 is het nullen van het toestel lastiger en is gekozen om de actuele nulwaarden te noteren en later, tijdens de gegevensverwerking voor de hogere nulwaarde te corrigeren. Na circa 3 dagen spoelen zijn de instrumenten uitgezet en klaargezet voor de volgende metingen.

De instrumenten worden jaarlijks teruggestuurd naar de leverancier voor onderhoud en justeren, gekoppeld aan een nieuw certificaat. Als op basis van de verkregen ruwe data blijkt dat de instrumenten niet betrouwbaar zijn, worden deze geëxcludeerd van de dataset voor verdere bewerking. Door een meettechnicus wordt vervolgens beoordeeld of het instrument moet worden opgestuurd voor justering. Bij herhaling van onbetrouwbare data bij een volgende meting zal het instrument zeker opgestuurd worden.

\section{CO2-analyse}

Testo type 435 met IAQ-probe voor $\mathrm{CO}_{2}$ en Vaisala $\mathrm{CO}_{2}$-sensor met Carbon Dioxide Probe GMP252.

De instrumenten hebben recente certificaten van de leverancier. Voordat de instrumenten in het onderzoek werden ingezet zijn ze geijkt in het eigen luchtlaboratorium. Middels het aanbieden van een verdunningsreeks $\mathrm{CO}_{2}$-kalibratiegas is de ijklijn van ieder instrument vastgesteld.

De Testo werd op een gegeven ogenblik instabiel en is daarna, na een gezamenlijke overbruggingsperiode, vervangen door de Vaisala-sensoren. De Vaisala-sensoren hebben geen eigen opslaggeheugen en zijn daardoor ingezet in combinatie met Koenders dataloggers.

\section{Temperatuur en relatieve luchtvochtigheid}

Escort RH iLogger EI-HS-D-32-L.

De logger staat ingesteld op een meetfrequentie van 2 minuten. Na iedere meting wordt het instrument goed schoongemaakt. Vervolgens komt het in een houder te liggen samen met enkele andere sensoren. Hierdoor kan een mogelijke afwijking worden vastgesteld. Deze loggers zijn niet recentelijk geijkt. Ze worden daarom slechts gebruikt ter indicatie van de meetomstandigheden.

Temperatuurbereik: $-40^{\circ} \mathrm{C}$ tot $+70^{\circ} \mathrm{C}$

Luchtvochtigheidsbereik: $0-100 \% \mathrm{RH}$

Nauwkeurigheid:

$\pm 0.35^{\circ} \mathrm{C}\left(\operatorname{van}-40^{\circ} \mathrm{C}\right.$ tot $\left.0^{\circ} \mathrm{C}\right)$

$\pm 0.25^{\circ} \mathrm{C}\left(\right.$ van $0^{\circ} \mathrm{C}$ tot $\left.+70^{\circ} \mathrm{C}\right)$

Luchtvochtigheid $\pm 3 \%$ 


\section{Bijlage 5 Concept BWL-beschrijving}

Let op! Dit is een concept ten tijde van publicatie van dit rapport.

\begin{tabular}{|c|c|c|}
\hline \multicolumn{2}{|c|}{ Nummer systeem } & BWL 2019.XX \\
\hline \multicolumn{2}{|c|}{ Naam systeem } & $\begin{array}{l}\text { Ionisatie d.m.v. koolstofborsteltjes; nn\% reductie fijnstof } \\
\left(\mathrm{PM}_{10}\right)\end{array}$ \\
\hline \multicolumn{2}{|c|}{ Diercategorie } & $\begin{array}{l}\text { Additionele technieken voor emissiereductie van fijn stof bij } \\
\text { pluimvee; ?? (categorieën uit Rav nog toevoegen) }\end{array}$ \\
\hline \multicolumn{2}{|c|}{ Systeembeschrijving van } & XXX 2019 \\
\hline \multicolumn{2}{|c|}{ Werkingsprincipe } & $\begin{array}{l}\text { De emissie van fijn stof }\left(\mathrm{PM}_{10}\right) \text { wordt beperkt door middel van het } \\
\text { geven van een lading aan de stofdeeltjes in de stal. Hiervoor } \\
\text { wordt in de stal een ionisatiesysteem met koolstofborsteltjes aangebracht } \\
\text { dat ionen verspreid. Door de lading binden de stofdeeltjes aan } \\
\text { watermoleculen in de lucht en worden de deeltjes zwaarder, deze } \\
\text { zwaardere deeltjes slaan neer op de grond. }\end{array}$ \\
\hline \multicolumn{3}{|c|}{ DE TECHNISCHE UITVOERING VAN HET SYSTEEM; BOUWKUNDIG } \\
\hline & Onderdeel & Uitvoeringseis \\
\hline 1 & \multicolumn{2}{|c|}{ Eisen volgens beschrijving waarmee systeem wordt gecombineerd. } \\
\hline \multicolumn{3}{|c|}{ DE TECHNISCHE UITVOERING VAN HET SYSTEEM; TECHNISCHE VOORZIENINGEN } \\
\hline & Onderdeel & Uitvoeringseis \\
\hline 2 & Huisvestingsvorm & Afhankelijk van diercategorie en huisvestingssysteem \\
\hline $3 a$ & \multirow[t]{4}{*}{ Ionisatiesysteem } & $\begin{array}{l}\text { De koolstofborsteltjes zijn aangebracht aan de behuizing van een } \\
\text { verlichtingssysteem }{ }^{5} \text {. }\end{array}$ \\
\hline $3 b$ & & Per $1.5 \mathrm{~m}^{2}$ staloppervlak minimaal 1 koolstofborsteltje. \\
\hline $3 c$ & & Per koolstofborsteltje worden minimaal $25 * 10^{6}$ ionen/s geproduceerd. \\
\hline $3 d$ & & $\begin{array}{l}\text { Plaatsing van de verlichtingsunits conform het plaatsingsplan van de } \\
\text { leverancier. }\end{array}$ \\
\hline 4 & Registratieapparatuur & $\begin{array}{l}\text { De volgende registratieapparatuur dient aanwezig te zijn: } \\
\text { - apparatuur voor het registreren van het in gebruik zijn van het } \\
\text { ionisatiesysteem (bijvoorbeeld urenteller, (k)Wh-meter) }\end{array}$ \\
\hline
\end{tabular}

\footnotetext{
${ }^{5}$ Voor een eerdere uitvoering van de ionisatielamp is een octrooi verleend onder nummer 1042530.
} 


\begin{tabular}{|c|c|c|}
\hline \multicolumn{3}{|c|}{ HET GEBRUIK VAN HET SYSTEEM } \\
\hline & Onderdeel & Gebruikseis \\
\hline$a$ & Leefoppervlak & $\begin{array}{l}\text { Aantal dieren } / \mathrm{m}^{2} \text { leefoppervlak volgens beschrijving waarmee systeem } \\
\text { wordt gecombineerd. }\end{array}$ \\
\hline$b$ & Ionisatie & Ionisatie vanaf 0 dagen na opzet ${ }^{6}$ \\
\hline c & Onderhoudscontract & $\begin{array}{l}\text { Het afsluiten van een onderhoudscontract met de leverancier of een } \\
\text { andere deskundige partij wordt sterk aanbevolen }{ }^{7} \text {. In het } \\
\text { onderhoudscontract zou een jaarlijkse controle en onderhoud van het } \\
\text { ionisatiesysteem moeten zijn opgenomen. Verder zijn in dit contract de } \\
\text { taken van de leverancier/deskundige partij opgenomen. }\end{array}$ \\
\hline$d$ & Registratie & $\begin{array}{l}\text { Ten behoeve van een controle op de werking van het systeem moeten } \\
\text { de volgende gegevens automatisch worden geregistreerd: } \\
\text { - het uitgestuurde voltage; } \\
\text { - het uitgestuurde amperage. } \\
\text { Van de geregistreerde waarden moet tijdens de controle een uitdraai } \\
\text { van de huidige en vorige productieperiode opvraagbaar zijn. }\end{array}$ \\
\hline \multicolumn{2}{|c|}{ Werkingsresultaat } & $\begin{array}{l}\text { Emissiereductie fijnstof }\left(\mathrm{PM}_{10}\right) \text { van } \mathrm{nn} \% \text { ten opzichte van de } \\
\text { emissiefactor van het stalsysteem waarmee het wordt gecombineerd. }\end{array}$ \\
\hline \multicolumn{2}{|c|}{ Verwijzing meetrapport } & $\begin{array}{l}\text { Pilots naar de vermindering van fijnstofemissie uit pluimveestallen: } \\
\text { HD-ionisatielampen van Freshlight (edepotnr toevoegen) }\end{array}$ \\
\hline
\end{tabular}

${ }^{6} \mathrm{Bij}$ de systemen waar eieren worden uitgebroed in de stal en daarna de kuikens in dezelfde stal worden opgefokt tot een bepaalde leeftijd (categorieën E 5.9.1.1 en E 5.9.1.2), de ionisatie inschakelen bij overplaatsen naar de vervolghuisvesting.

${ }^{7}$ Een onderhoudscontract is een goed middel om te voorkomen dat de gebruiker problemen krijgt bij het afleggen van een verantwoording bij de handhaving. 

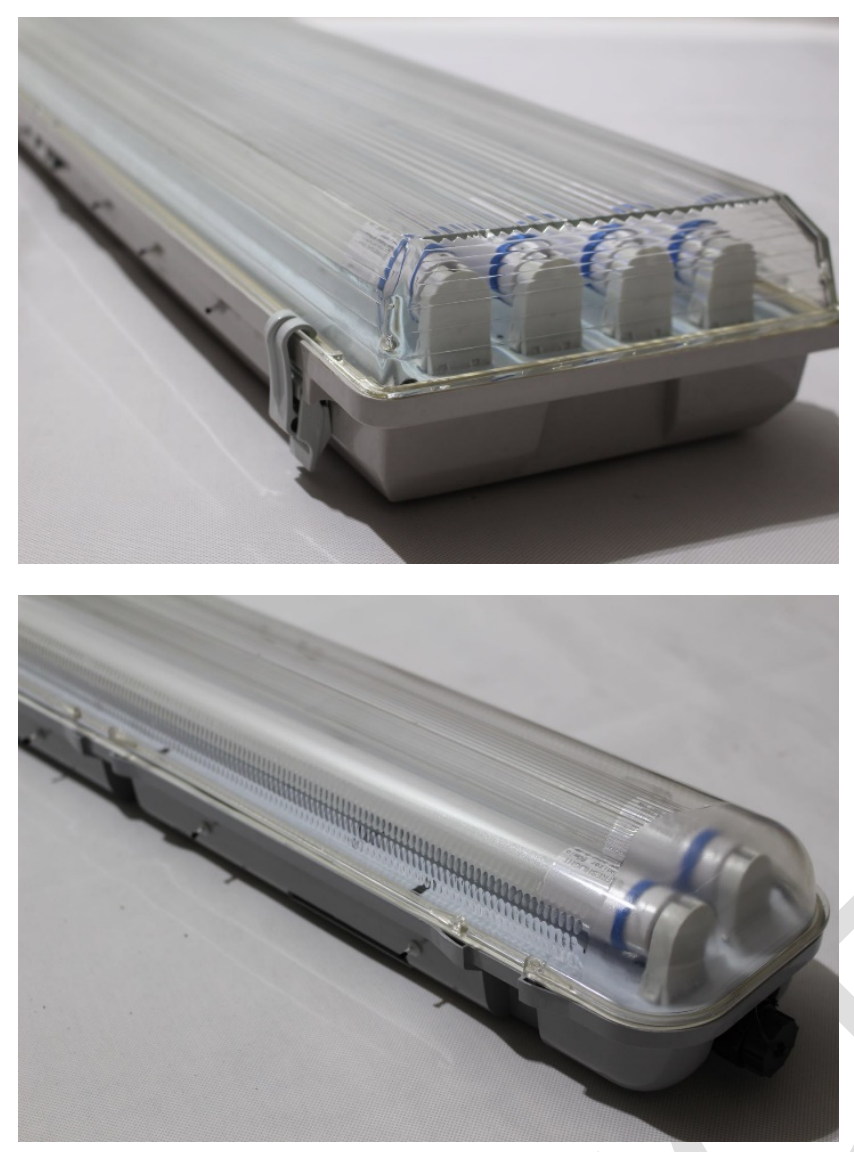

\begin{tabular}{|l|l|}
\hline Naam: & Nummer: \\
Ionisatie d.m.v. & BWL 2019.XX \\
\cline { 2 - 2 } koolstofborsteltjes; & Systeembeschrijving: \\
nn\% reductie & XXX 2019 \\
fijnstof $\left(\mathrm{PM}_{10}\right)$ & \\
\hline
\end{tabular}



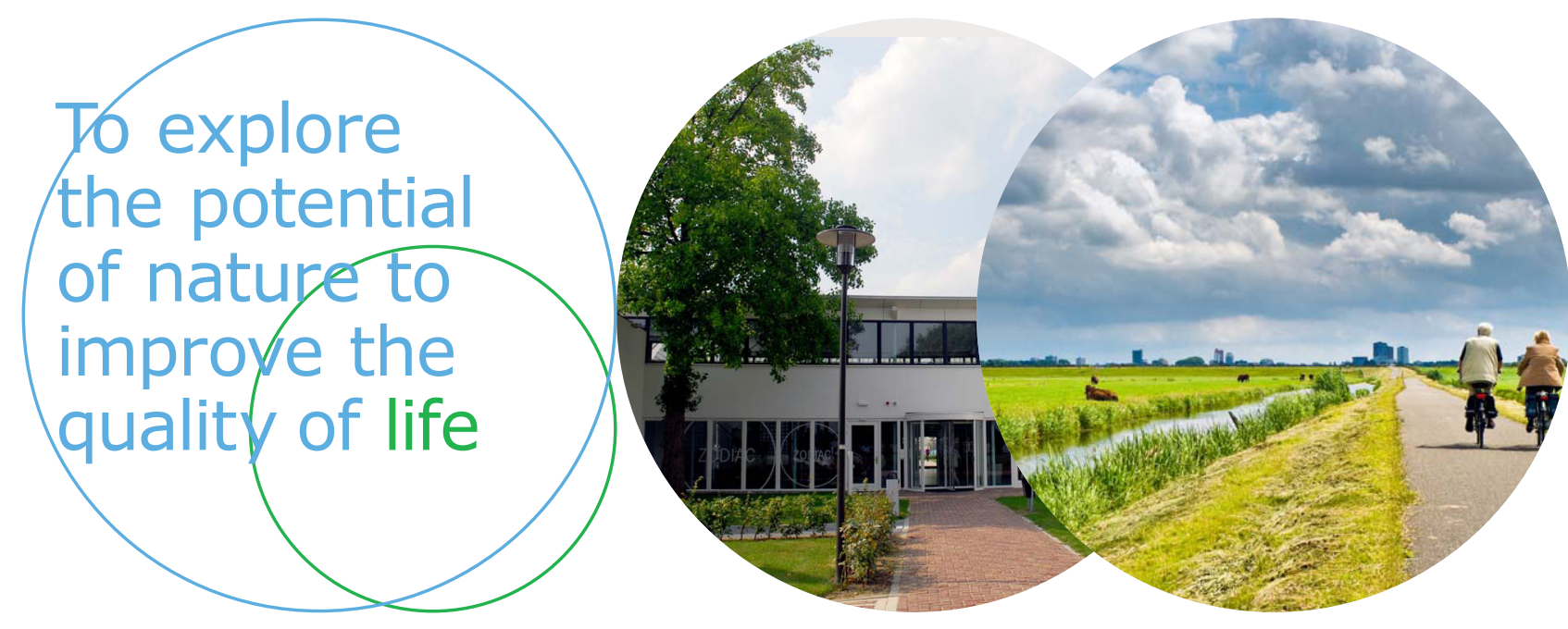

Wageningen Livestock Research Postbus 338

$6700 \mathrm{AH}$ Wageningen

T 0317483953

E info.livestockresearch@wur.nl www.wur.nl/livestock-research
Wageningen Livestock Research ontwikkelt kennis voor een zorgvuldige en renderende veehouderij, vertaalt deze naar praktijkgerichte oplossingen en innovaties, en zorgt voor doorstroming van deze kennis. Onze wetenschappelijke kennis op het gebied van veehouderijsystemen en van voeding, genetica, welzijn en milieu-impact van landbouwhuisdieren integreren we, samen met onze klanten, tot veehouderijconcepten voor de $21 \mathrm{e}$ eeuw.

De missie van Wageningen University \& Research is 'To explore the potential of nature to improve the quality of life'. Binnen Wageningen University \& Research bundelen 9 gespecialiseerde onderzoeksinstituten van Stichting Wageningen Research en Wageningen University hun krachten om bij te dragen aan de oplossing van belangrijke vragen in het domein van gezonde voeding en leefomgeving. Met ongeveer 30 vestigingen, 6.500 medewerkers en 10.000 studenten behoort Wageningen University \& Research wereldwijd tot de aansprekende kennisinstellingen binnen haar domein. De integrale benadering van de vraagstukken en de samenwerking tussen verschillende disciplines vormen het hart van de unieke Wageningen aanpak. 